\title{
Privacidade e corpo: convergências possíveis ${ }^{*}$
}

\section{Privacy and body: possible convergences}

\author{
Carlos Nelson Konder*
}

\section{Resumo}

O artigo propõe uma leitura historicamente contextualizada das convergências entre o direito à privacidade e a proteção jurídica do corpo. Parte da concepção moderna do "direito a ser deixado só" e da indisponibilidade do corpo aborda os desafios impostos pelas pressões do mercado e demandas por segurança para chegar à privacidade como autodeterminação informativa e ao corpo como informação, ilustrando com as situações da redesignação sexual, da proteção dos dados genéticos e do direito de não saber.

Palavras-chave: Privacidade. Corpo. Informação.

\section{Abstract}

This paper intends to realize a historical approach to the convergences between right to privacy and law protection of the body. It begins in the modern conception of the "right to be let alone" and the indisponibility of the body, approaches the challenges of the market pressures and demands for security, and arrives at the conceptions of privacy as informational self-determination and body as information, exemplifying with the cases of transsexuals, genetic information protection and the right not to know.

Keywords: Privacy. Body. Information.

* Artigo desenvolvido no âmbito do projeto Casadinho/Procad entre a Faculdade de Direito da UERJ e a Unifor.

** Professor adjunto de Direito Civil da Universidade do Estado do Rio de Janeiro (UERJ) e da Pontifícia Universidade Católica do Rio de Janeiro (PUC-Rio). Doutor e mestre em Direito Civil pela UERJ. Especialista em Direito Civil pela Universidade de Camerino (Itália). Rio de Janeiro RJ - Brasil. E-mail: c.konder@gmail.com 


\section{Introdução}

"Quite an experience to live in fear, isn't it? That's what it is to be a slave" Ridley Scott, Blade Runner.

Privacidade e corpo são conceitos que, embora familiares, sofreram dramáticas modificações em seu significado e alcance conforme as circunstâncias históricas que os produziram. Assim, entender o significado de direito à privacidade e de direito ao corpo demanda compreender o contexto histórico-social em que eles se encontram. Diferentes épocas e locais deram origem a concepções bastante diversas do que deva ser a proteção jurídica da privacidade e qual o estatuto jurídico do corpo, tornando esses institutos excelentes "termômetros" para indicar os valores, os desejos e os medos que, numa dada sociedade, davam conteúdo ao seu direito civil.

Trata-se de construções sociais que são corolários do processo de transformação histórica da separação entre a esfera pública e a esfera privada. Ainda que na maior parte das sociedades se possa inferir essa divisão ${ }^{1}$, os termos de sua colocação, a amplitude e a importância de cada espaço são historicamente construídos. "Espaço público" e "espaço privado", "casa" e "rua", "jardim" e "praça” são espaços sociais que, embora referidos por termos bastante similares, variam drasticamente em seu significado. A partir da reformulação da separação entre o público e o privado, com a valorização dos espaços de privacidade, constroem-se, na sociedade moderna, as rígidas separações entre autoridade e liberdade, política e economia, Estado e sociedade, direito

\footnotetext{
Afirma Duby (2009, p. 10): "[...] sempre e por toda parte, exprime-se no vocabulário o contraste, diretamente detectado pelo senso. De que uma área particular, claramente delimitada, é atribuída a essa parte da existência que todas as línguas denominam privada, uma zona de imunidade oferecida ao recolhimento, onde todos podemos abandonar as armas e as defesas das quais convém nos munir ao arriscar-nos no espaço público; onde relaxamos, onde nos colocamos à vontade, livres da carapaça de ostentação que assegura proteção externa. Esse lugar é de familiaridade. Doméstico. Íntimo. No privado encontra-se o que possuímos de mais precioso, que pertence somente a nós mesmos, que não diz respeito a mais ninguém, que não deve ser divulgado, exposto, pois é muito diferente das aparências que a honra exige guardar em público".
} 
e moral, e, dentro do direito, a dicotomia entre direito público e direito privado (TEPEDINO, 2005).

No entanto, com o desenrolar da modernidade, também no campo do direito, privacidade e corpo se ressignificam, razão pela qual um esforço para compreender suas convergências atuais impõe partir de uma contextualização histórica.

\section{A privacidade como o "direito a ficar só"}

As reconstruções históricas do direito à privacidade costumam fundar-se em um episódio especialmente ilustrativo de embate entre uma atriz famosa de personalidade forte e um grande jornal que relatava ao público os detalhes de sua vida. Em 1890, Marian Manola, em uma cena da peça de teatro "Castles in the air", na qual aparecia com roupas íntimas, viu-se surpreendida pelo espocar do flash da câmera de um fotógrafo do The New York Times (Myers), que se escondera entre os objetos cenográficos no palco. Transtornada ao compreender o que tinha ocorrido, Marian se cobriu com um cobertor e fugiu do palco no meio do espetáculo, vindo depois a dar origem ao processo "Manola vs. Myers" junto à Suprema Corte de Nova York² (GLANCY, 1990, online). Esse acontecimento fez com que os juristas Warren e Brandeis publicassem, no mesmo ano, na Harvard Law Review, um artigo em que divulgavam o direito à privacidade como um amplo right to bet let alone, concepção posteriormente adotada expressamente pela Suprema Corte americana $^{3}$.

Trata-se da versão original da concepção amplamente difundida entre nós do direito à privacidade como o "direito a ficar só" ou o "direito

2 O jornal The New York Times chegou a escrever, em 3 de setembro de 1894, lamentando que a carreira da atriz tivesse chegado ao fim por conta de seus crescentes rompantes de insanidade (“Marion Manola's sad fate". Disponível em: <http://migre.me/ciKaF>). Acesso em: 18 ago.2013.

3 Nos termos dos autores, "the protection afforded to thoughts, sentiments, and emotions, expressed through the medium of writing or of the arts, so far as it consists in preventing publication, is merely an instance of the enforcement of the more general right of the individual to be let alone. It is like the right not to be assaulted or beaten, the right not to be imprisoned, the right not to be maliciously prosecuted, the right not to be defamed" (BRANDEIS; WARREN, 1890). 
a ser deixado só"; a proteção jurídica de espaços livres de vigilância para o desenvolvimento da personalidade; a defesa de uma existência pessoal única contra perturbações exteriores, como o assédio e a observação.

Sob essa acepção original, a proteção jurídica da privacidade tinha como corolários a tutela da imagem; o sigilo profissional, de comunicações e bancário; e a inviolabilidade de domicílio. A principal ameaça a esse direito era identificada na imprensa, que começava a ganhar destaque na sociedade civil ${ }^{4}$. Tornou-se popular sua estruturação sob o modelo de círculos concêntricos: à esfera mais ampla da privacidade sucedia a mais restrita da intimidade, acessível somente a pessoas muito próximas, e, enfim, a esfera do segredo, contendo aquilo a que somente seu titular tinha acesso ${ }^{5}$.

Ela decorre da concepção de um indivíduo isolado, ao qual o ordenamento permite a prerrogativa de "murar-se" contra agressões alheias. O sucesso da proteção à privacidade pressupõe, sob esse ponto de vista, a ausência de interferências externas. Trata-se de uma garantia jurídica de isolamento.

Constatam-se, nesse modelo de privacidade, características marcantes do pensamento jurídico próprio do paradigma moderno, enraizadas no jusnaturalismo, positivadas nos Códigos Civis com a ascensão da burguesia ao poder, difundidas pelo mundo em virtude da influência desses "monumentos legislativos" e do grande desenvolvimento da doutrina nesse período histórico, enfim, consolidadas sub-repticiamente nos institutos jurídicos de que nos utilizamos até hoje.

Três dessas características saltam aos olhos. Primeiro, o individualismo jurídico, que, segundo Hespanha (1998), desabrocha no

\footnotetext{
$4 \quad$ "Instantaneous photographs and newspaper enterprise have invaded the sacred precincts of private and domestic life; and numerous mechanical devices threaten to make good the prediction that 'what is whispered in the closet shall be proclaimed from the house-tops." (BRANDEIS; WARREN, 1890).

5 A construção da teoria é atribuída a um debate entre Heinrich Henkel e Heinrich Hubmann, e foi difundida entre nós por Costa Júnior (1970). Para uma visão crítica dessa construção, v. Doneda (2006), e Bruno Lewicki (1998).
} 
Direito sob a égide de uma concepção de natureza humana individualista e racional, apoiada pelo racionalismo cartesiano e pelo nominalismo de Guilherme d'Ockham, de modo que o sistema jurídico é todo construído a partir do indivíduo como valor original e fundamental e da pressuposição de direitos inatos, atribuídos pelo caráter naturalmente justo do poder da vontade.

Segundo, o viés patrimonialista, em virtude de sua similitude com o modelo paradigmático do direito de propriedade ${ }^{6}$. Estruturalmente, isso se identifica na contraposição do direito subjetivo a um dever geral negativo - "não se entra na propriedade, não se entra na vida privada" - e, funcionalmente, pelos valores e destinatários protegidos: um direito burguês, que não atingia os excluídos e marginalizados (SCHREIBER, 2011).

Terceiro, o viés voluntarista, também próprio do paradigma moderno de racionalidade. A importância de uma avaliação do querer individual se destaca nas decisões americanas até hoje, na medida em que a privacidade é protegida comumente com base no que seria uma legítima expectativa de privacidade, parâmetro normalmente referido entre nós para a tutela das relações contratuais. Tome-se como exemplo a recente decisão da Suprema Corte limitando a utilização de cães farejadores nos arredores de residências, sob o fundamento de que "o policial foi até a parte da casa em que se espera privacidade" e tomando por base "as expectativas de um dono de casa razoável"7.

6 A semelhança é observada pelos próprios autores: "What is the nature, the basis, of this right to prevent the publication of manuscripts or works of art? It is stated to be the enforcement of a right of property; and no difficulty arises in accepting this view, so long as we have only to deal with the reproduction of literary and artistic compositions. They certainly possess many of the attributes of ordinary property: they are transferable; they have a value; and publication or reproduction is a use by which that value is realized. But where the value of the production is found not in the right to take the profits arising from publication, but in the peace of mind or the relief afforded by the ability to prevent any publication at all, it is difficult to regard the right as one of property, in the common acceptation of that term." (BRANDEIS; WARREN, 1890).

7 São os casos "Florida vs. Jardines", n. 11-564, e "Florida vs. Harris", n. 11-817, julgados em 31 de outubro de 2012. As referências aos casos estão disponíveis em: <http://migre.me/fOEo3>. Acesso em: 20 ago. 2013. Sobre a referência a uma "expectativa razoável de privacidade", v. Solove (2002, p. 1090). 
Deve-se reconhecer, todavia, que tais características, naquele contexto histórico, foram importantes para tornar a privacidade um importante instrumento de proteção de minorias, garantia da liberdade individual, desenvolvimento da personalidade e tutela do pluralismo (RODOTÀ, 2008).

A afirmação da autonomia individual, ainda que pautada por uma tutela da vontade em moldes patrimoniais, constituiu-se em um meio de emancipação do sujeito frente às restrições externas, de raízes reputadas, morais e culturais, como se observa no tocante ao tratamento jurídico do corpo.

\section{0 corpo intocável}

A vinculação do corpo à fisiologia natural e, especialmente, à sexualidade do ser humano conduziu para que, mesmo nos períodos de maior afirmação da liberdade individual, pesasse sobre a autonomia corporal uma série de limitações. Invocadas sob o falacioso argumento da "natureza humana", tais restrições constituem, na verdade, como não podia deixar de ser, imposições culturais - por vezes, verdadeiros tabus.

Como destaca Rodrigues (1986, p. 44), "o corpo humano é socialmente concebido, e [...] a análise da representação social do corpo oferece uma das numerosas vias de acesso à estrutura de uma sociedade particular." Ainda que exista um conjunto de motivações biológicas comuns à espécie, a atribuição de significação especial a tais motivações é cultural e, portanto, historicamente construída. (RODRIGUES, 1986).

Isso é perceptível quando se pensa na modificação corporal. Embora presente em diversas culturas, suas manifestações e significados são determinados pelo contexto.

Assim, é significativo que entre nós haja um gradiente próprio entre certas práticas admitidas e por vezes estimuladas, como tatuagens, piercings e bodybuilding; outras repudiadas pela cultura mainstream, 
embora toleradas, como implantes subcutâneos, escarificação e suspensão; e outras, ainda, que, embora taxadas de patológicas, são frequentes e, portanto, também reflexo de certas características da nossa sociedade, como branding, cutting, amputações e distúrbios alimentares, como a bulimia e a anorexia ${ }^{8}$.

No entanto, sob o paradigma moderno, à existência de um "direito ao próprio corpo" foi reputada uma impossibilidade lógica, decorrente da necessária distinção entre sujeito e objeto do direito (LEMENNICIER, 1991). Ainda que se reconheça a inadequação da utilização da estrutura do direito subjetivo para a efetivação de uma autonomia corporal, é necessário reconhecer também que, nessa seara, não há impossibilidades lógicas nem escolhas naturais. O conteúdo cultural e político das restrições à disposição do corpo se revela quando o legislador elege quais critérios devem ser utilizados para liberar ou restringir o uso do corpo pelo sujeito.

Por exemplo, persiste entre nós um enunciado legislativo representativo dessa mentalidade restritiva. Trata-se do artigo 13 do Código Civil vigente, o qual veda os atos de disposição do próprio corpo que importem diminuição permanente da integridade física ou violação aos bons costumes, exceto por exigência médica ${ }^{9}$. O dispositivo consegue conjugar as três vertentes de discursos restritivos: a naturalização, a medicalização e a moralização.

Embora toda a comunidade jurídica atual repudie qualquer forma de exigência de "forma humana" para a atribuição de personalidade (PEREIRA, 2010), no tocante ao corpo, persiste a referência ao "corpo normal", conforme o "padrão da natureza", para limitar os atos de

8 Como explica Ortega (2008, p. 61): "O desarraigamento social e a ausência de vínculos simbólicos e rituais coletivos conduzem o indivíduo a se retrair sobre si e fazer de seu corpo um universo em miniatura, uma verdade sobre si e um sentimento de realidade, que a sociedade não consegue mais lhe fornecer."

9 "Art. 13. Salvo por exigência médica, é defeso o ato de disposição do próprio corpo quando importa diminuição permanente da integridade física, ou contrariar os bons costumes." 
disposição ${ }^{10}$. Atos de disposição permanente - como a amputação de um membro - traduzem a ideia de retirada do padrão natural do corpo e por isso são vedados. Esse é o caso dos chamados wannabes ou amputeesby-choice, pessoas que, movidas por um profundo desejo de adequar seu corpo a uma visão própria de identidade, buscam voluntariamente a amputação de um membro, mas, impedidas pelas restrições legais e regulamentares, muitas vezes recorrem a um mercado negro de amputações, com consequências desastrosas para sua saúde ${ }^{11}$.

Esse discurso só cede diante do discurso da medicalização. 0 paternalismo médico, próprio do paradigma racionalista da modernidade, autoriza o legislador a abrir mão da proteção à naturalidade e à moralidade, em nome da voz mais forte da ciência. Assim, tanto a anormalidade como a imoralidade passam a ser consentidas se autorizadas pelo médico, entidade a quem se atribui o poder de determinar o que é saudável e correto do ponto de vista científico ${ }^{12}$. Esse foi o mecanismo que autorizou juridicamente as cirurgias de modificação sexo: somente com a classificação da transexualidade como uma doença - a disforia de gênero - a cirurgia passou a surgir como cura, enquadrando-se, portanto, no critério da finalidade terapêutica ${ }^{13}$.

Mas certamente o mais significativo e ilustrativo dos critérios legais de indisponibilidade do corpo encontra-se na vedação dos atos disposição contrários aos bons costumes. Aqui, o legislador abre a porta para que o Judiciário possa recriminar qualquer forma de exercício da autonomia corporal que se entenda contrário a um determinado padrão de moralidade, cuja definição fica ao arbítrio do intérprete ${ }^{14}$.

\footnotetext{
10 Sobre o tema, v. Foucault (2001) e Canguilhem (2000).

11 Sobre o tema, v. Konder (2003, pp. 41-71).

12 Entre as diversas abordagens do tema, v. Michel Foucault (1977) e, entre nós, Barboza (2012, pp. 481-497); Birman (2007, pp. 529-548); Martins e Junior (2009, pp. 157-165).

13 V. item. 10, infra.

14 Para um esforço de interpretação do termo à luz da Constituição, v.
} 


\section{0 mercado e o preço da autonomia}

Esse cenário moderno, banhado pelo desenvolvimento do paradigma racionalista, guiado por uma concepção de sujeito individualista, patrimonialista e racionalista, mas, ao mesmo tempo, prenhe de preconceitos e tabus no que diz respeito à esfera existencial, confronta-se, nas últimas décadas, com desafios cada vez maiores.

O primeiro, certamente, é a importância do mercado. Na medida em que os bens existenciais se tornam as mercadorias mais valiosas, o tratamento da personalidade arrisca ser submetido aos moldes negociais tipicamente patrimonialistas, e a pessoa e suas informações mais íntimas são recorrentemente vendidas sob o manto da falaciosa liberdade formal, que nunca é suficiente nas relações desiguais. Como explica Rodotà (2008, p. 113):

Tudo isso é apresentado como um preço compulsório para fruir das crescentes oportunidades oferecidas pela sociedade da informação. Concretamente, isso significa que a contrapartida necessária para se obter um bem ou um serviço não se limita mais à soma de dinheiro solicitada, mas é necessariamente acompanhada por uma cessão de informações. Nessa troca, então, não é mais somente o patrimônio de uma pessoa que está envolvido. A pessoa é obrigada a expor seu próprio eu, sua própria persona, com consequências que vão além da simples operação econômica e criam uma espécie de posse permanente da pessoa por parte de quem detém as informações a seu respeito.

O valor econômico da informação torna ainda mais lucrativa a violação à privacidade, assim como enseja a proliferação de meios indiretos de usurpação de dados pessoais. É ilustrativa desse problema a declaração de Marissa Mayer, CEO do Yahoo, de que "a privacidade é sempre objeto de venda, porque quando você abre mão de algumas de suas informações, você ganha alguma funcionalidade em troca"15.

\footnotetext{
15 No original, "privacy is always a trade-off. Because when you give up some of your information you get some functionality in return" (apud GREENFIELD, 2013).
} 
Os dados pessoais, nesse contexto, tornam-se bens patrimoniais, disponíveis, renunciáveis e até transmissíveis causa mortis. Simbólico disso é o instrumento oferecido pelo Google que permite a disposição de suas informações para depois da morte, nos moldes das disposições testamentárias. O Inactive Account Manager é um gerenciador que permite decidir qual será o destino dos seus dados quando você morrer, quem será comunicado e quem terá acesso a eles ${ }^{16}$.

De modo geral, constata-se uma perigosa patrimonialização das situações existenciais, em que o respeito ao espaço de autodeterminação dos sujeitos para decidir sobre a forma mais adequada de livremente desenvolver sua personalidade resvala para a tolerância com a mercantilização de aspectos fundamentais da dignidade humana. No âmbito da privacidade, construções jurídico-sociais como "garoto(a) s-propaganda", "pessoas públicas" e "reality shows" são exemplos ilustrativos dessa tendência ${ }^{17}$. Nessa seara, a melhor doutrina destaca a necessidade de se garantir uma tutela qualitativamente diversa das situações existenciais, em comparação com as situações patrimoniais (PERLINGIERI, 2002).

O problema vai da tutela da privacidade e das informações pessoais à própria proteção jurídica do corpo da pessoa. A notícia de garotas japonesas que alugam as próprias coxas por cerca de trinta dólares para a divulgação de peças publicitárias nas ruas de Tóquio (PUBLICITÁRIO..., 2013, on-line) traz à tona a discussão sobre os limites à comercialização do corpo, sempre suscitada nos debates sobre prostituição, "barriga de aluguel" e venda de órgãos, sangue e gametas. Como destaca Rodotà (2010), é importante diferenciar autonomia e desespero.

16 Informações disponíveis em: <http://migre.me/fOEly>. Acesso em: 20 ago. 2013. V. ainda Garattoni (2013).

17 Sobre o tema, v. Teixeira e Konder (2012, pp. 3-24). 


\section{0 medo e o homem de vidro}

O segundo desafio diz respeito à importância que, numa era de incertezas, o discurso da segurança passou a assumir ${ }^{18}$. O crescimento da sensação de ameaça constante e medo de atos de violência conduz ao apoio a mecanismos de controle, monitoramento e vigilância. Como descreve Bauman (2009, p. 63), "a arquitetura do medo e da intimidação espalha-se pelos espaços públicos das cidades, transformando-a sem cessar - embora furtivamente - em áreas extremamente vigiadas, dia e noite".

Esses mecanismos de controle e vigilância são, inevitavelmente, restrições ao exercício da privacidade e do corpo. Autodeterminação se contrapõe, logicamente, a toda forma de heterodeterminação na circulação de dados e corpos. Assim, qualquer mecanismo de vigilância, qualquer forma de monitoramento é, necessariamente, a atribuição a um terceiro do poder de coletar, administrar e utilizar informações alheias.

Isso envolve uma ponderação, encontrando parâmetros e procedimentos pelos quais a vigilância não sacrifique demasiadamente a privacidade. No entanto, deve-se reconhecer que a balança entre a afirmação da autonomia e a instituição de sistemas de vigilância tem, nos últimos anos, pendido mais para o segundo lado. Como alerta Rodotà (2008, p. 14):

Depois do 11 de setembro, 'a privacidade na era do terror' parece estar condenada. A privacidade, além de não ser mais vista como um direito fundamental, é, de fato, frequentemente considerada um obstáculo à segurança, sendo superada por legislações de emergência.

No cenário norte-americano, como é cediço, o grande impulso vem da ameaça terrorista. De início, a tradição individualista e liberal, calcada na afirmativa dos direitos fundamentais, ensejou uma configuração peculiar da privacidade. Não prevista no texto constitucional, seus

18 Sobre o tema, v. Bodin de Moraes (2010, pp. 33-54). 
contornos variam muito de estado para estado e sua construção se deu de forma pragmática, conforme se encontravam situações que não conseguiam ser satisfatoriamente tuteladas pela propriedade privada ou pela confidencialidade. Assim, embora tenha ampla aplicação e diversas fontes e formas, quase equivalendo a um "direito geral da personalidade", o right to privacy não possui uma unidade clara (DONEDA, 2006).

Os sacrifícios à proteção da privacidade americana em nome da vigilância já eram recorrentes no âmbito do combate à criminalidade, como pode ser exemplificado nos registros de condenados por crimes sexuais após o cumprimento de suas penas. Em diversos estados, os condenados que já cumpriram suas penas continuam a ter sua identidade e seu domicílio divulgados em listas da internet, por força de lei, e a Suprema Corte já decidiu por duas vezes pela constitucionalidade de tais leis ${ }^{19}$.

Os atentados terroristas de 11 de setembro de 2001 impulsionaram ainda mais a atenuação do direito à privacidade. No cenário americano, a partir da edição do Patriot Act um mês após os atentados ${ }^{20}$, diversas medidas foram tomadas para ampliar os poderes de investigação das autoridades administrativas. O exemplo mais polêmico foi, com base no Homeland Security Act, o desenvolvimento do Total Information Awareness, posteriormente renomeado como Terrorism Information Awareness (TIA). O programa, apenas uma das diversas iniciativas do Information Awareness Office, visava levar a mineração de dados (data mining) a um novo nível, integrando todos os bancos de dados de todas as agências governamentais americanas e os bancos de dados comerciais, de maneira a facilitar a identificação de terroristas ${ }^{21}$ (TAIPALE, 2003).

19 Em "Connecticut Dept. of Public Safety vs. Doe", no sentido de que a lei estadual não feria o princípio do devido processo legal (http://migre.me/fOEJ9) e em "Smith vs. Doe", no sentido de que o registro não é uma punição retroativa (http://migre.me/fOEJi). Acesso em: 20 ago. 2013.

20 A íntegra do "Uniting and Strengthening America by Providing Appropriate Tools Required to Intercept and Obstruct Terrorism (USA Patriot Act) act of 2001". Disponível em: <http://migre.me/ fOEJG>. Acesso em: 20 ago. 2013.

21 O programa, constituído a partir do Homeland Security Act, deixou de ser financiado pelo Congresso Americano em 2006, mas agências de notícias informaram que ele foi apenas realocado para outras agências governamentais (HARRIS, 2006). 
Doneda (2006), em estudo comparativo sobre o tema, indica que o modelo adotado no âmbito da União Europeia é diverso: enquanto o americano se pauta em uma concepção fragmentária de privacidade, disponível, negociável e sacrificável com base no interesse público de segurança, na Europa, a proteção de dados pessoais ganhou tratamento amplo e sistemático. As Diretivas 95/46/CE, 97/66/CE e 2002/58/CE instituíram um sistema no qual são expressamente tuteladas a qualidade dos dados, a legitimidade do seu tratamento, o direito de oposição ao seu tratamento, a confidencialidade e segurança ${ }^{22}$. Coloca-se, então, em questão qual será trilhado pelo ordenamento brasileiro.

\section{A resposta brasileira}

O problema não está distante do cenário nacional. Embora a ameaça do terrorismo não seja comum no imaginário brasileiro, a violência urbana é um fantasma recorrente a alimentar as demandas por mais vigilância e menos privacidade. Não se trata de desprezar o dramático aumento da criminalidade violenta nas principais cidades do país, mas de reconhecer que os discursos sobre essas ameaças são modificados, amplificados e dirigidos contra certos alvos ${ }^{23}$.

No âmbito da atividade estatal, o debate se acirra com o novo Registro de Identidade Civil (RIC), com o qual cada cidadão passa a ter um número nacional baseado em suas impressões digitais. No projeto, ainda em fase inicial, os dados biométricos estarão armazenados em um banco de dados unificado, chamado Cadastro Nacional de Registro de Identificação Civil24.

22 Disponível em: <http://migre.me/fOEL2>, <http://migre.me/fOELb> e <http://migre.me/fOELr>, respectivamente. Acesso em: 20 ago. 2013.

23 Nesta linha, v. Batista (2006, p. 209-232).

24 O Decreto $n^{\circ} 7.166$, de 5 de maio de 2010 - criou o Sistema Nacional de Registro de Identificação Civil, instituiu seu Comitê Gestor, determinou que o Sistema Nacional de Registro de Identificação Civil terá como órgão central o Ministério da Justiça e regulamentou disposições da Lei $n^{\circ} 9.454$, de 7 de abril de 1997, com nova redação dada pela Lei 12.058 de 14 de outubro de 2009. 
Também polêmica, a Lei 12.654/2012 prevê a coleta de material biológico por ocasião da identificação criminal, com o fim de obtenção do perfil genético do acusado. O perfil será armazenado em um banco de dados gerenciado por uma unidade oficial de perícia criminal. Destacase que os dados terão caráter sigiloso, respondendo civil, penal e administrativamente aquele que permitir ou promover sua utilização para fins diversos dos previstos na lei ou em decisão judicial. Além disso, as informações genéticas não poderão revelar traços somáticos ou comportamentais das pessoas, exceto determinação genética de gênero, consoante as normas constitucionais e internacionais sobre direitos humanos, genoma humano e dados genéticos.

Merece destaque ainda o Sistema Nacional de Identificação Automática de Veículos (SINIAV), criado pela Resolução n²12/2006 do Conselho Nacional de Trânsito (CONTRAN), segundo o qual até 30 de junho de 2014 todos os veículos automotores possuirão um chip contendo número de série do chip, identificação da placa, categoria e tipo do veículo. Além disso, emitirá sinais de radiofrequência a serem captados por antenas espalhadas pelas cidades e rodovias ${ }^{25}$. Entre os objetivos do programa, estão a localização de carros furtados, a diminuição da clonagem de placas e a fiscalização da velocidade dos automóveis e da circulação em locais e horários proibidos. Entretanto, o programa vem causando grande receio no tocante à utilização indevida das informações colhidas ${ }^{26}$.

Da mesma forma, trazem grande preocupação as referências ao Mosaico, um programa que, tal qual o Prism americano, estaria permitindo à Agência Brasileira de Inteligência (ABIN) coletar informações de usuários do Facebook, Twitter, Instagram e Whatsapp (MARTINS, 2013). Assim como a notícia de investigações requeridas pela International Federation for Human Rights (FIDH) e pela World Organization Against

\footnotetext{
25 Informações oficiais do Portal Brasil disponíveis em: <http://migre.me/fOEMk> Acesso em: 20 ago. 2013.

26 Dados disponíveis em: <http://siniav.net/>. Acesso em: 20 ago. 2013. Para uma análise crítica, v. Moraes (2013) e Doneda (2013).
} 
Torture (OMCT) acerca de atividades ilegais de inteligência envolvendo mineração de dados (data mining) (BRAZIL, 2013).

Nesse cenário, o principal instrumento legal em defesa da privacidade é o habeas data. Reconhece-se que é um recurso subestimado quanto à sua importância, pois traz potencialidades ainda pouco utilizadas. No entanto, mesmo que se faça uso de tudo aquilo que ele oferece, é um recurso insatisfatório. Principalmente porque a maior parte dos problemas mencionados se processa em branco, isto é, sem que o interessado sequer perceba sua ocorrência, e o habeas data depende de uma provação ao Judiciário para desempenhar seu papel de proteção à privacidade (DONEDA, 2006).

No entanto, novas iniciativas legislativas se desvelam. O debate acerca dos desaparecidos durante o regime militar ensejou diversas medidas a fim de favorecer um sistema mais transparente com relação aos dados coletados pelo Estado. Nesse sentido, deve ser destacada a Lei Geral de Acesso à Informação (Lei 12.527/2011), que delimita as possibilidades de se estabelecer o sigilo de certos dados e regula 0 direito de acesso a informações sob a guarda do Estado ${ }^{27}$.

Lege ferenda, vale destacar não apenas o bastante debatido na mídia Projeto de Lei do Marco Civil da Internet (PLC 2126/2011), que, entre outros aspectos, visa garantir a privacidade do usuário na rede mundial de computadores, mas principalmente o PLC 4060/2012, que dispõe especificamente sobre o tratamento de dados pessoais, atualmente apensado ao PLC 3558/2012, sobre dados biométricos.

As iniciativas legislativas são bem-vindas, pois no Judiciário persiste uma lógica mais próxima do paradigma moderno de tutela. O patrimonialismo, por exemplo, destaca-se nas decisões com uma tendência a pautar os julgados também pela aplicação da lógica proprietária (patrimonial) à lógica da privacidade e da proteção ao corpo (existencial), utilizando-se daquela visão simplista de que coisas

27 Para uma visão crítica da lei, v. Nunes (2013). 
abandonadas (derrelitas), como o lixo, não são mais abrangidas pela privacidade, de que fatos exteriores à propriedade privada, isto é, em espaço público, não podem ser considerados informações protegidas.

A patrimonialização na jurisprudência brasileira é complementada pelos já referidos aspectos individualista e voluntarista do paradigma moderno, pelos quais a privacidade é entendida como bem transacionável e renunciável, passível de ampla disposição a partir da autonomia negocial de seu titular, mesmo de forma tácita. Como destaca Lôbo (2008, p. 105),

a banalização da autolimitação da privacidade está provocando a própria desconsideração social ou ruína desta, pois as pessoas passam a encarar como normal sua violação, inclusive quando afeta frontalmente o núcleo essencial da dignidade humana.

Exemplificando essa orientação, o Superior Tribunal de Justiça (STJ) decidiu que a banhista que faz topless na praia não pode pleitear indenização para o jornal que divulgou sua foto em primeira página, levando sua imagem seminua de uma praia local para o grande público ${ }^{28}$.

Essa indevida simplificação - que implica a patrimonialização da metodologia do tratamento da pessoa - se destaca especialmente nas decisões do binômio "pessoa notória/lugar público". De maneira geral, difundiu-se o entendimento de que certas pessoas, em virtude de sua notoriedade na mídia, teriam a priori uma "privacidade reduzida",

28 BRASIL. STJ, $4^{\text {a }}$ T., Resp. 595.600, Rel. Min. Cesar Asfor Rocha, julg. 18.03.2004, publ. RDR 31/442, em cuja ementa se lê: "Direito civil. Direito de imagem. Topless praticado em cenário público. Não se pode cometer o delírio de, em nome do direito de privacidade, estabelecer-se uma redoma protetora em torno de uma pessoa para torná-la imune de qualquer veiculação atinente a sua imagem. Se a demandante expõe sua imagem em cenário público, não é ilícita ou indevida sua reprodução pela imprensa, uma vez que a proteção à privacidade encontra limite na própria exposição realizada. Recurso especial não conhecido." Sobre a decisão, afirmou Lôbo (2008, p. 103): "O fato de a pessoa ter conduta diferente das demais, sem prejuízo a quem quer que seja e inexistindo lei proibitiva, é exercício de sua liberdade, constitucionalmente assegurada, não se podendo entender que autorizou tacitamente a publicação violadora de sua privacidade, na medida em que o jornal atingiu público maior que o do lugar onde se encontrava, com evidente intuito sensacionalista". 
sob o argumento de que, como ganham seu sustento a partir de sua fama e reconhecimento em público, teriam que suportar o ônus de serem interpeladas, fotografadas e filmadas $^{29}$ (TEIXEIRA, 2012). A lógica se complementa pelo critério jurídico-geográfico do "lugar público", que, aplicando a lógica patrimonial, firma a premissa de que somente informações colhidas dentro da propriedade privada estariam guarnecidas pelo direito à privacidade. Como destaca Lewicki (2006), o binômio "pessoa pública/local público" serviu para justificar tanto a leitura labial de técnico de futebol em campo quanto a captura de imagens de atriz e cantor em momentos íntimos na praia.

Espera-se que as iniciativas legislativas, conjugadas pelos esforços da doutrina, revertam essa tendência jurisprudencial. É necessário reconhecer que a privacidade e a tutela do corpo, como situações jurídicas existenciais, requerem tratamento metodológico diferenciado, que não pode ser simplificado nos termos binários da lógica proprietária.

O artigo 21 do Código Civil, que prevê a proteção da privacidade sob o respaldo do art. $5^{\circ}, \mathrm{X}$, da Constituição, deve ser entendido como uma cláusula geral, de maneira a ampliar a tutela dos espaços de desenvolvimento da personalidade (MORAES, 2010), assim como o art. 43 do Código de Defesa do Consumidor, que protege as informações dos consumidores constantes em bancos de dados, tem vocação expansiva para aplicar-se a relações jurídicas não consumeristas em que haja vulnerabilidade do titular dos dados (SCHREIBER, 2011). Os dispositivos em questão, amparados por uma interpretação constitucionalizada, permitem temperar os rigores impostos pelo já referido artigo 13 do Código Civil, assim como pelo artigo $11^{30}$, na medida em que, como resultado de uma ponderação dos princípios envolvidos, resguardam um espaço de autonomia existencial sobre o qual o legislador não pode atuar impondo barreiras sem amparo na dignidade da pessoa humana.

\footnotetext{
29 Sobre o tema, v. Teixeira e Konder (2012, p. 12).

30 "Art. 11. Com exceção dos casos previstos em lei, os direitos da personalidade são intransmissíveis e irrenunciáveis, não podendo o seu exercício sofrer limitação voluntária.”
} 
Não é possível olvidar o papel fundamental que desempenha a autonomia na configuração da privacidade e do corpo, permitindo que o titular possa configurar o controle de seus dados como the for mais adequado, no exercício do livre desenvolvimento de sua personalidade. No entanto, deve ficar claro que o exercício dessa autonomia na esfera existencial não pode se pautar pelos mesmos instrumentos e parâmetros utilizados para as situações patrimoniais.

\section{Demandas contemporâneas}

Como visto, o tratamento moderno da privacidade e do corpo sobreviveu, continua a ser aplicado na maior parte da jurisprudência e invocado pela maior parte da doutrina. As transformações do contexto histórico-social que lhe deu origem, todavia, revelam cada dia mais sua insuficiência. $O$ direito a ser deixado só torna-se apenas um atributo de um feixe de prerrogativas que deve ser mais amplo (SOLOVE, 2002). Proteção ao corpo, como instrumento do livre desenvolvimento da personalidade, não se efetiva por barreiras arbitrárias incompatíveis com a autonomia existencial.

As transformações são exigidas por duas forças complementares. Em primeiro lugar, a transformação valorativa do ordenamento. As conquistas no âmbito da Psicologia e da Comunicação Social conduziram à constatação de que o indivíduo isolado, que basta a si mesmo, representado pelo personagem de Robinson Crusoé, é um mito incondizente com pessoas que nascem, vivem e morrem em grupos, e cujas identidades são culturalmente construídas (PLASTINO, 1996). Assim, também no âmbito do Direito, o sujeito humano não pode ser concebido como uma microcélula autônoma (o homo clausus): a abertura em relação aos outros é uma necessidade, de maneira que a solidariedade torna-se princípio jurídico, com força normativa, cuja realização é requisito para a tutela da dignidade da pessoa humana (MORAES, 2010b).

Diante disso, encontra-se um impulso inicial à necessária modificação ou ampliação da privacidade. A proteção exclusiva de um 
espaço de construção da intrassubjetividade se revela insatisfatória na medida em que a identidade e a personalidade não podem prescindir, para o seu desenvolvimento, da relação com os demais sujeitos. Dessa forma, insere-se no debate sobre o conceito e o alcance da privacidade a dimensão da intersubjetividade (MORAES, 2010c).

Em segundo lugar, a transformação técnica da realidade. Assim como a modernidade conviveu com drásticas transformações tecnológicas em razão da Revolução Industrial e ganhou características próprias na forma como lidou com essas mudanças, o impacto das novas tecnologias na contemporaneidade também repercutiu sobre a vida cotidiana atual.

O efeito da evolução dos sistemas de telecomunicações sobre as relações privadas não pode ser menosprezado se compararmos a dinâmica de uma sociedade pautada na correspondência epistolar, na qual a televisão e o telefone surgiram como eletrodomésticos de residências privilegiadas, com a dinâmica de uma comunidade globalmente ligada, em tempo real, através da internet, em que computadores pessoais são substituídos por tablets e smartphones e as interações se dão por redes sociais e microblogs ${ }^{31}$.

\section{A privacidade como "autodeterminação informativa"}

Como pensar o "direito a ficar só" e a proteção de uma esfera de isolamento em uma comunidade virtual cujos membros já estão a quilômetros de distância, mas cuja exposição pessoal é maior e mais frequente do que entre vizinhos de condomínio? A proteção da privacidade contra agressões alheias demanda reformulação quando não é mais possível demarcar com clareza a separação entre a "esfera interna" e as "interferências externas".

31 Já fazia o alerta entre nós, em 1989, Tepedino (2008, pp. 561-563). 
Nesse contexto, o bem jurídico mais precioso, mais procurado, mais transacionado e, justamente, menos protegido, é a informação ${ }^{32}$. Significativamente denominada "sociedade da informação", essa comunidade se calca na virtualização dos bens sob a forma de dados minimamente processados e organizados para serem utilizados e transferidos. Não é à toa que uma das marcas mais valiosas do mundo seja um buscador de informações ${ }^{33}$.

Técnicas de "mineração de dados" (data mining) permitem, dentro do amplo manancial de informações já disponíveis na rede - fornecidas pelos titulares devido aos mais variados motivos e nos mais diversos contextos -, a seleção daquelas úteis e valiosas e sua reconstrução sob nova formatação. Viabiliza-se, assim, a contínua construção de "perfis" (profiling) destinados a identificar pessoas, grupos, famílias ou territórios com base em seu comportamento e preferências ${ }^{34}$.

A maior parte dessas informações é pessoal, tem por objeto a própria pessoa humana; e parte significativa configura os chamados "dados sensíveis", isto é, dados pessoais e familiares cuja divulgação, em virtude de seu conteúdo (sentimentos, conduta sexual, saúde, defeitos físicos, fé religiosa, ideias políticas), tem repercussões especialmente prejudiciais ao livre desenvolvimento da personalidade (DONEDA, 2006).

É nesse contexto que se insere a reformulação ou expansão do conceito de privacidade, na necessidade de uma proteção mais ampla e eficaz da circulação dessas informações pessoais. Trata-se de

\footnotetext{
32 Sobre a informação como bem jurídico, v. Perlingieri (2012, p. 963 e ss).

33 O buscador Google foi considerado a quarta marca mais valiosa do mundo nos anos de 2011 e 2012 (INTERBRAND, 2012). Destaque-se, ainda, os recorrentes casos de venda de números de CPF anunciados na rede (entre outros, <http://migre.me/cje5L>. Acesso em: 09 dez. 2012).

34 Sobre o tema, v. Doneda (2006, p. 173-180).
} 
conceder a cada um de nós um poder real de controle sobre nossos dados, enunciado como o direito à autodeterminação informativa ${ }^{35}$.

A prerrogativa do titular deixa a esfera íntima para ir onde os dados estão; protege não apenas contra o invasor da casa, o voyeur, mas contra o acesso a qualquer banco de dados que contenha informações pessoais. Passa-se do domicílio à rede, do sigilo à circulação, da proteção estática à proteção dinâmica, de um poder de exclusão a um poder de controle (RODOTÀ, 2008). No contexto descrito, somente dessa forma se permite efetivamente a liberdade para a construção da esfera privada.

Não se trata de abandonar as garantias liberais modernas do sigilo de comunicação e da inviolabilidade de domicílio, mas de expandir a proteção da privacidade sobre uma nova área, sob uma nova forma. Para além do "direito ao respeito pela sua vida privada e familiar, pelo seu domicílio e pelas suas comunicações", reconhece-se também o

direito à proteção dos dados de caráter pessoal que lhes digam respeito, [que] devem ser objeto de um tratamento leal, para fins específicos e com o consentimento da pessoa interessada ou com outro fundamento legítimo previsto por lei [e o] direito de aceder aos dados coligidos que thes digam respeito e de obter a respectiva retificação ${ }^{36}$.

35 A expressão tem origem em uma decisão da Corte Constitucional alemã de 15 de dezembro de 1983 sobre a constitucionalidade do censo populacional (Bundesverfassungsgericht, decisions, v. 65, p. 1 ff. (apud HORNUNG; SCHNABEL, 2009, pp. 84-88). Disponível em: <http://migre.me/ fOETX>. Acesso em: 20 ago.2013. Na explicação de Rodotà, "[...] a privacidade deve ser vista como 'a proteção de escolhas de vida contra qualquer forma de controle público e estigma social' (FRIEDMAN), como a 'reivindição dos limites que protegem o direito de cada indivíduo a não ser simplificado, objetivado, e avaliado fora de contexto' (ROSEN). [...] Estas definições não são mutuamente exclusivas, marcam uma inclusão progressiva de novos aspectos de liberdade num conceito ampliado de privacidade" (RODOTÀ, 2008, p. 15). Solove, por sua vez, entende que não é mais possível definir a privacidade com base em um "núcleo duro", em requisitos necessários e suficientes, mas com base em semelhanças e familiaridades, sob uma perspectiva pragmática. O autor lista seis linhas de definição da privacidade (o direito a ser deixado só, a limitação de acesso, o segredo, a autodeterminação informativa, a personalidade, intimidade) (SOLOVE, 2002, p. 1090).

36 Arts. $7^{\circ}$ e $8^{\circ}$, respectivamente, da Carta dos Direitos Fundamentais da União Europeia (2013). 
Inviabilizada a simples proibição de coleta, trata-se de regulamentar a coleta e o tratamento dos dados coletados, conferindo, para além do aspecto substancial, um aspecto procedimental ao direito à privacidade (SCHREIBER, 2011). Nesse sentido, a própria efetivação do direito à privacidade não pode se restringir aos moldes da proteção individual e ganha uma dimensão coletiva, demandando sua viabilização por meio de instrumentos transindividuais e de autoridades administrativas especialmente constituídas para esse fim (RODOTÀ, 2008).

O procedimento passa a ser orientado por diversos princípios, como a transparência (ou publicidade), que determina o conhecimento público e a autorização prévia quanto à existência do banco de dados; a exatidão das informações; a indicação da finalidade do cadastro, que restringirá seu uso; o livre acesso dos dados pelos seus titulares; e a segurança, no sentido da proteção contra extravio, destruição, transmissão ou acesso não autorizado (DONEDA, 2006).

\section{0 corpo como informação}

Constatado que a revolução tecnológica é um dos principais impulsos à necessidade de reformulação da privacidade, deve-se indicar ainda que ela não se resume ao âmbito das telecomunicações. Os enormes progressos, de dramáticas repercussões, na biotecnologia têm um impacto significativo e peculiar no tocante à reconstrução do direito à privacidade.

O mal-estar produzido pelas possíveis consequências éticas dessas novas tecnologias biomédicas deu origem à chamada bioética, o "estudo sistemático da conduta humana no âmbito das ciências da vida e da saúde à luz de valores e princípios morais"37 (REICH, 1979).

\footnotetext{
37 Ressalta Barboza (2000, p. 210): "Talvez esse [seja] o maior mérito da Bioética: sistematizar (ou ao menos tentar) o tratamento de questões diversas, mas que devem guardar entre si, necessariamente, princípios e fins comuns."
} 
A partir de estudos iniciais, diretivas e orientações éticas, passou-se à consagração de normas de conduta (deontológicas) e jurídicas, o chamado biodireito (BARBOZA; BARRETTO, 1999).

Essas alterações sobre o significado do corpo têm um impacto direto no plano do Direito ${ }^{38}$. O corpo de hoje encontra-se transformado em comparação com sua concepção moderna. Segundo Rodotà (2009), o corpo foi dissociado, distribuído, virtualizado e colocado em rede (networked).

A dissociação do corpo decorre de sua fragmentação em partes, cada qual com sua autônoma relevância jurídica. Órgãos, tecidos, células, gametas e o próprio código genético (DNA) são ponto de referência de relações jurídicas, objeto de direitos e deveres. É ilustrativa do início dessa expansão a decisão, em 1993, da Corte de Cassação alemã (Bundesgerichtshof), segundo a qual a destruição do sêmen congelado de um cliente de 31 anos, que o depositara antes de se submeter a uma cirurgia que poderia deixá-lo estéril, configurava uma forma de lesão corporal, a justificar o dever de indenizar (BGHZ 124, 2013).

No âmbito nacional, a referência é o caso Glória Trevi, cantora que alegou ter sido estuprada enquanto estava encarcerada nas dependências da polícia federal, mas se recusou a fornecer material biológico seu e do feto para o exame de DNA comparativo com o material colhido de 61 funcionários e detentos suspeitos. O exame foi feito sobre a placenta contra a vontade da cantora, respaldado pela opinião dominante do STF, o qual entendeu que a placenta era alheia ao corpo e o interesse individual da cantora não poderia prevalecer

38 Neste sentido, "a forma como o homem entende o próprio corpo e com ele se relaciona é contextual e cultural, portanto, heterogênea e mutável, por razões várias, sejam de matriz antropológica, filosófica, religiosa, sociológica ou técnico-científica, as quais se refletem na apreensão jurídica do corpo humano". (MACHADO, 2009, p. 39). 
sobre o interesse público relativo à segurança pública e à moralidade administrativa ${ }^{39}$.

A distribuição do corpo, a partir de sua dissociação, operase espacialmente. Antes concentrado em um único local, hoje está espalhado no mundo. Os bancos de gametas (tanto de sêmen como de óvulos), a criopreservação de tecidos e os transplantes de órgãos colocam dificuldades nas quais as partes do corpo não mais se encontram integradas sob o domínio físico do seu titular. Essa distribuição revela um desafio para a tutela da pessoa - e de seu corpo - que não pode ser enfrentado pelos moldes modernos, uma vez que a pessoa, se deixada só, já não está sequer em companhia do próprio corpo.

39 "Reclamação. Reclamante submetida ao processo de Extradição n. ${ }^{\circ} 783$, à disposição do STF. 2. Coleta de material biológico da placenta, com propósito de se fazer exame de DNA, para averiguação de paternidade do nascituro, embora a oposição da extraditanda. 3. Invocação dos incisos X e XLIX do art. $5^{\circ}$, da CF/88. 4. Ofício do Secretário de Saúde do DF sobre comunicação do Juiz Federal da $10^{\mathrm{a}}$ Vara da Seção Judiciária do DF ao Diretor do Hospital Regional da Asa Norte - HRAN, autorizando a coleta e entrega de placenta para fins de exame de DNA e fornecimento de cópia do prontuário médico da parturiente. 5 . Extraditanda à disposição desta Corte, nos termos da Lei n. ${ }^{\circ} 6.815 / 80$. Competência do STF, para processar e julgar eventual pedido de autorização de coleta e exame de material genético, para os fins pretendidos pela Polícia Federal. 6. Decisão do Juiz Federal da $10^{a}$ Vara do Distrito Federal, no ponto em que autoriza a entrega da placenta, para fins de realização de exame de DNA, suspensa, em parte, na liminar concedida na Reclamação. Mantida a determinação ao Diretor do Hospital Regional da Asa Norte, quanto à realização da coleta da placenta do filho da extraditanda. Suspenso também o despacho do Juiz Federal da $10^{\mathrm{a}}$ Vara, na parte relativa ao fornecimento de cópia integral do prontuário médico da parturiente. 7. Bens jurídicos constitucionais como 'moralidade administrativa', 'persecução penal pública' e 'segurança pública' que se acrescem, - como bens da comunidade, na expressão de Canotilho, - ao direito fundamental à honra ( $C F$, art. $\left.5^{\circ}, \mathrm{X}\right)$, bem assim direito à honra e à imagem de policiais federais acusados de estupro da extraditanda, nas dependências da Polícia Federal, e direito à imagem da própria instituição, em confronto com o alegado direito da reclamante à intimidade e a preservar a identidade do pai de seu filho. 8 . Pedido conhecido como reclamação e julgado procedente para avocar o julgamento do pleito do Ministério Público Federal, feito perante o Juízo Federal da $10^{\mathrm{a}}$ Vara do Distrito Federal. 9. Mérito do pedido do Ministério Público Federal julgado, desde logo, e deferido, em parte, para autorizar a realização do exame de DNA do filho da reclamante, com a utilização da placenta recolhida, sendo, entretanto, indeferida a súplica de entrega à Polícia Federal do 'prontuário médico' da reclamante". (BRASIL. STF, Pleno, Rcl 2040 QO, Rel. Min. Néri da Silveira, julg. 21/02/2002). Para uma análise crítica da decisão, v. Machado (2009, pp. 17-52). 
Mas é na virtualização que se dá o verdadeiro salto. O corpo, por suas partes, é transformado em dados biométricos ${ }^{40}$ : impressão digital, formato da face, da íris e da palma da mão, até o timbre de voz - padrões corporais que servem para individualizar o sujeito frente ao resto da coletividade e podem ser traduzidos em uma informação, como um dado, um código de barras ou uma cifra alfanumérica. Segundo Rodotà (2004, p. 91), "na information age, o corpo foi desde logo considerado como um conjunto de dados, um sistema informativo".

Uma vez virtualizado, o corpo entra na rede. As informações biométricas podem deslocar-se livremente, de forma instantânea, integrar bancos de dados, serem analisadas, processadas e manipuladas para formar perfis.

A forma mais agressiva de integração dos corpos na rede se dá através dos implantes de chips que transmitem informações sobre a identidade, o estado de saúde, a localização geográfica e outros dados pessoais. Recebe-se com receio as notícias de lançamentos de implantes de chips corporais como o Very Pay, pela empresa americana Applied Digital Soluctions, com o objetivo de substituir o cartão de crédito comum; o da mexicana Xega, para rastreamento em caso de seqüestro; ou o da City Watcher, para controle de funcionários no acesso a áreas reservadas de empresa (TEIXEIRA, 2008). No Brasil, entre os casos mais recentes, estão as notícias sobre a utilização de chips para monitoramento de alunos em escola do Distrito Federal (ESCOLA..., 2013, on-line) e jogadores de futebol enquanto estão em campo (JOGADORES..., 2013, on-line).

A transformação do corpo converge com a transformação do direito à privacidade, uma vez que, para muitos, o primeiro sempre foi o coração do segundo: a privacidade sempre envolveu a ocultação de certas partes do corpo, o segredo sobre certas condições e doenças, as

40 Afirma Rodotà (2008, p. 248): "O corpo está se tornando uma senha, o seu caráter físico toma o lugar das palavras-chave abstratas, através de impressões digitais, íris, traços de face, DNA.” 
regras de toque e contato interpessoal, o controle individual e o domínio sobre as decisões a respeito do próprio corpo (SOLOVE, 2002).

Nessa linha, até mesmo para a satisfação de uma concepção mais ampla de saúde, é necessário resguardar a autonomia corporal ${ }^{41}$. Sob essa perspectiva, a recusa à transfusão de sangue pelos testemunhas de Jeová, a alimentação forçada de pessoas em greve de fome e o pleito pela amputação voluntária dos wannabes, assim como as formas de modificação corporal, seriam questões abrangidas no debate mais amplo sobre o direito à privacidade e seu impacto sobre o corpo.

Assim, também do ponto de vista formal, há uma alteração importante: o consentimento em relação à redução ou renúncia de aspectos normalmente tutelados pela privacidade deve revestir-se do qualificativo de consentimento informado, mais precisamente, consentimento livre e esclarecido ${ }^{42}$. Pode-se conceituá-lo como a livre anuência do sujeito após explicação completa e pormenorizada sobre a intervenção, incluindo: sua natureza, objetivos, métodos, duração, justificativa, possíveis males, riscos e benefícios, alternativas existentes, nível de confidencialidade dos dados, assim como sua liberdade total para recusar ou interromper o procedimento a qualquer momento, tendo o profissional a obrigação de informá-lo em linguagem adequada (não técnica) para que seja compreensível (KONDER, 2003; CASABONA, 2005, BARBOZA, 2008). Tradicionalmente invocado no âmbito médico, esse instrumento materializa diversos dos já invocados princípios para o tratamento de dados, como a finalidade, a transparência e a segurança. Alguns exemplos controversos servem para ilustrar os termos contemporâneos da ligação entre corpo e privacidade

\footnotetext{
41 Sobre o tema, v. Teixeira (2010).

42 Como explica Rodotà (2008, p. 75), "também no que diz respeito ao consentimento, ocorreram evoluções significativas à medida que, abandonando a técnica do implied consente, ocupou o centro das atenções, com especificações cada vez mais analíticas, o informed consent. E creio ser útil ressaltar como a disciplina do informed consent se exprime também em regras sobre a circulação das informações, visto que se manifesta em uma série de disposições que prescrevem quais devam ser as informações fornecidas ao interessado para que seu consentimento seja validamente expresso".
} 


\section{Privacidade e redesignação sexual}

Um grande exemplo de convergência entre a privacidade como autodeterminação informativa e o corpo como informação se verifica no tratamento jurídico da transexualidade. A jurisprudência brasileira experimentou uma considerável evolução no tratamento dessa questão nos últimos anos. As primeiras decisões, possivelmente alimentadas pelo ainda dominante desconhecimento a respeito da situação em questão, vinham fundamentadas em diversos preconceitos e eram claramente incompatíveis com a exigência de proteção integral à dignidade da pessoa humana. Em que pese reconhecerem a orientação do Conselho Federal de Medicina, no sentido de que a cirurgia era o tratamento adequado para disforia de gênero, recusavam-se a conferirIhe qualquer efeito jurídico no tocante à alteração registral do nome e do sexo, sob argumentos como a indisponibilidade do status e o caráter apenas aparente da cirurgia, uma vez que não realiza uma alteração nos órgãos internos, ou, nos termos de um dos julgadores, "quem nasce homem ou mulher, morre como nasceu. Genitália similar não é autêntica. Autêntico é o homem ser do sexo masculino e a mulher do feminino, a toda evidência" 43 .

43 RIO DE JANEIRO. Tribunal de Justiça do Rio de Janeiro - TJRJ, 8a C.C., Ap. Civ. 1993.001.06617, rel. des. Geraldo Batista, v.u., julg. 18/03/1997. Eis a íntegra da ementa: "REGISTRO CIVIL DE nascimento. Nome. RetificaÇÃo. Mudança do seXo. Impossibilididae. Retificação no Registro Civil. Mudança de nome e de sexo. Impossibilidade. Sentença mantida. O homem que almeja transmudar-se em mulher, submetendo-se a cirurgia plástica reparadora, extirpando os órgãos genitais, adquire uma 'genitália' com similitude externa ao órgão feminino, não faz jus à retificação de nome e de sexo porque não é a medicina que decide o sexo e sim a natureza. Se o requerente ostenta aparência feminina, incompatível com a sua condição de homem, haverá de assumir as conseqüências, porque a opção foi dele. O Judiciário, ainda que em procedimento de jurisdição voluntária, não pode acolher tal pretensão, eis que a extração do pênis e a abertura de uma cavidade similar a uma neovagina não tem o condão de fazer do homem, mulher. Quem nasce homem ou mulher, morre como nasceu. Genitália similar não é autêntica. Autêntico é o homem ser do sexo masculino e a mulher do feminino, a toda evidência". Na mesma linha, TJRS, $3^{\text {a }}$ C.C., Ap. Civ. 597156728, rel. des. Tael João Selistre, julg. 18/12/97; e TJRJ, $4^{a}$ C.C., Ap. Civ. 1992.001.06087, e o caso notório de Luis Roberto Gambine Moreira, conhecido como Roberta Close, cuja primeira decisão foi negativa ("Registro CIVIL de nAscimento. Prenome. RetificaçÃo. Mudança do sexo. Registro civil. Retificação de sexo. Prenome. Cirurgia de ablação da genitália masculina, considerada mutiladora, não tem o condão de transformação de sexo. Problema de engenharia genética inafastável. Prevalência do sexo natural sobre o psicológico. Sexo não é opção, mas determinismo biológico, estabelecido na fase da gestação. Apelo provido. (JRC)" (TJRJ, $8^{a}$ C.C., Ap. Civ. n. 1993.001.04425, rel. des. Luiz Carlos Guimarães, julg. 10/05/1994, publ. RF 328/196; RT 712/235). 
A difusão do entendimento de que a construção da identidade sexual não se pauta exclusivamente pelo sexo morfológico, cromossomial ou genético, aliada à ampla proteção da liberdade de orientação sexual, contribuíram para que as decisões autorizando a alteração de nome e, posteriormente, do registro de sexo pudessem ser efetuadas (PERES, 2001). Reconheceu-se que tal alteração era parte essencial do livre desenvolvimento da personalidade, sob pena de condenar os envolvidos a uma vida de discriminação e humilhação ao carregar no registro uma identidade que não condizia com sua apresentação social ${ }^{44}$.

Com isso, a jurisprudência brasileira, anos depois, alcançava o que se considerava o nível de proteção máxima desse tipo de situação, que já fora imposto à França pela Corte Europeia de Direitos Humanos, exatamente sob o fundamento da proteção à privacidade. Mais especificamente, em 1992, a Corte Europeia de Direitos Humanos condenou os tribunais franceses a reverem a negativa de retificação de registro a um transexual, entendendo que a falta de modificação do registro constituía uma violação ao art. $8^{\circ}$ da Convenção Europeia de Direitos Humanos, o qual determina a proteção à vida privada e familiar ${ }^{45}$.

No âmbito do Superior Tribunal de Justiça, também se pode observar essa evolução após uma decisão monocrática que homologou sentença estrangeira de alteração de registro (BRASIL. STJ, SE 1.058, Rel. Min. Barros Monteiro, julg. 15.08.2006). O primeiro caso efetivamente apreciado por turma foi de um transexual feminino que ajuizou pedido de alteração de registro após ter sido submetido à cirurgia de redesignação do sexo. No Tribunal de Justiça do Rio Grande

44 Para uma visão da discriminação da transexualidade à luz da figura do homo sacer de Agamben, v. Barboza (2010).

45 Disponível em: <http://migre.me/fOF2d>. Acesso em: 14 jan. 2013. Pousson-Petit (1994, pp. 143147), destacou na ocasião que, no Direito Comparado, poderiam ser identificados três níveis de reconhecimento do estatuto jurídico do transexual: um nível mínimo, como no Direito inglês, no qual se admite a intervenção médica, mas não se permite a alteração do registro civil (salvo o prenome); um nível intermediário, como na Espanha e na Bélgica, que reconhece o transexual com restrições ou omissões, constituindo um 'terceiro sexo'; e um nível ótimo, como na Itália e na Holanda, onde, apesar do pleno reconhecimento da mudança de sexo, ainda restam lacunas sobre certos efeitos jurídicos da alteração. 
do Sul, o pedido foi julgado procedente e se afirmou que a alteração do registro deveria ser mantida em segredo de justiça: a informação ou certidão sobre a mudança não poderia ser dada a terceiros, salvo no atendimento de requisição judicial. Contudo, o STJ reformou a decisão para permitir somente a averbação e não a retificação do registro, sob o argumento de que a mudança de sexo era um ato voluntário que não poderia ser escondido. Nas palavras do relator ${ }^{46}$.

No presente feito, não se examina o direito do recorrido de mudar de sexo, mas, apenas, se esse direito alcançado deve, ou não, constar dos registros, devidamente averbado o fato de que houve modificação cirúrgica do sexo. [...] Não se pode esconder no registro, sob pena de validarmos agressão à verdade que ele deve preservar, que a mudança decorreu de ato judicial, nascida da vontade do autor e que tornou necessário ato cirúrgico complexo. Trata-se de registro imperativo e com essa qualidade é que se não pode impedir que a modificação da natureza sexual fique assentada para o reconhecimento do direito do autor. Conheço do especial e lhe dou provimento para determinar que fique averbado no registro civil que a modificação do nome e do sexo do recorrido decorreu de decisão judicial.

No entanto, o precedente foi superado apenas dois anos depois. Em outro julgado, o STJ manifestou o entendimento de que "vetar a alteração do prenome do transexual redesignado corresponderia a mantê-lo em uma insustentável posição de angústia, incerteza e conflitos,

46 "Mudança de sexo. Averbação no registro civil. 1. O recorrido quis seguir o seu destino, e agente de sua vontade livre procurou alterar no seu registro civil a sua opção, cercada do necessário acompanhamento médico e de intervenção que lhe provocou a alteração da natureza gerada. Há uma modificação de fato que se não pode comparar com qualquer outra circunstância que não tenha a mesma origem. O reconhecimento se deu pela necessidade de ferimento do corpo, a tanto, como se sabe, equivale o ato cirúrgico, para que seu caminho ficasse adequado ao seu pensar e permitisse que seu rumo fosse aquele que seu ato voluntário revelou para o mundo no convívio social. Esconder a vontade de quem a manifestou livremente é que seria preconceito, discriminação, opróbrio, desonra, indignidade com aquele que escolheu o seu caminhar no trânsito fugaz da vida e na permanente luz do espírito. 2. Recurso especial conhecido e provido" (BRASIL. STJ, $3^{a}$ T., REsp 678.933-RS, Rel. Min. Carlos Alberto Menezes Direito, julg. 22.03.2007). Para uma análise crítica da decisão, v. Thamis Ávila Dalsenter (2007, p. 193-206). 
que inegavelmente atinge a dignidade da pessoa humana assegurada pela Constituição Federal", e assim passou a autorizar a retificação com base na proteção da identidade sexual ${ }^{47}$.

Hoje, a controvérsia inicial parece superada e a discussão sobre o tema se inova à luz de discussões sobre a possibilidade de alteração de registro sem a cirurgia médica e a redesignação sexual de menores, hipóteses cujo mero debate seria inconcebível há alguns anos.

\section{Os dados genéticos como dados "sensíveis"}

O desenvolvimento da genética é certamente uma das principais contribuições ao reconhecimento do corpo como informação e, em convergência, espaço para a atuação da privacidade como autodeterminação informativa. Afirma-se que os estudos sobre a informação genética do ser humano, principalmente a partir do projeto Genoma, desencadearam no âmbito internacional o desenvolvimento

47 "Direito civil. Recurso especial. Transexual submetido à cirurgia de redesignação sexual. Alteração do prenome e designativo de sexo. Princípio da dignidade da pessoa humana. - Sob a perspectiva dos princípios da Bioética - de beneficência, autonomia e justiça -, a dignidade da pessoa humana deve ser resguardada, em um âmbito de tolerância, para que a mitigação do sofrimento humano possa ser o sustentáculo de decisões judiciais, no sentido de salvaguardar o bem supremo e foco principal do Direito: o ser humano em sua integridade física, psicológica, socioambiental e ético-espiritual. - A afirmação da identidade sexual, compreendida pela identidade humana, encerra a realização da dignidade, no que tange à possibilidade de expressar todos os atributos e características do gênero imanente a cada pessoa. Para o transexual, ter uma vida digna importa em ver reconhecida a sua identidade sexual, sob a ótica psicossocial, a refletir a verdade real por ele vivenciada e que se reflete na sociedade. - A falta de fôlego do Direito em acompanhar o fato social exige, pois, a invocação dos princípios que funcionam como fontes de oxigenação do ordenamento jurídico, marcadamente a dignidade da pessoa humana - cláusula geral que permite a tutela integral e unitária da pessoa, na solução das questões de interesse existencial humano. - Em última análise, afirmar a dignidade humana significa para cada um manifestar sua verdadeira identidade, o que inclui o reconhecimento da real identidade sexual, em respeito à pessoa humana como valor absoluto. - Somos todos filhos agraciados da liberdade do ser, tendo em perspectiva a transformação estrutural por que passa a família, que hoje apresenta molde eudemonista, cujo alvo é a promoção de cada um de seus componentes, em especial da prole, com o insigne propósito instrumental de torná-los aptos de realizar os atributos de sua personalidade e afirmar a sua dignidade como pessoa humana. - A situação fática experimentada 
de uma nova geração - ou dimensão - de direitos humanos (XAVIER, 2004). Nessa linha, a Declaração Universal sobre o Genoma Humano e os Direitos Humanos considera o genoma humano simbolicamente patrimônio da humanidade, insuscetível de transações financeiras em

pelo recorrente tem origem em idêntica problemática pela qual passam os transexuais em sua maioria: um ser humano aprisionado à anatomia de homem, com o sexo psicossocial feminino, que, após ser submetido à cirurgia de redesignação sexual, com a adequação dos genitais à imagem que tem de si e perante a sociedade, encontra obstáculos na vida civil, porque sua aparência morfológica não condiz com o registro de nascimento, quanto ao nome e designativo de sexo. - Conservar o "sexo masculino" no assento de nascimento do recorrente, em favor da realidade biológica e em detrimento das realidades psicológica e social, bem como morfológica, pois a aparência do transexual redesignado, em tudo se assemelha ao sexo feminino, equivaleria a manter o recorrente em estado de anomalia, deixando de reconhecer seu direito de viver dignamente. - Assim, tendo o recorrente se submetido à cirurgia de redesignação sexual, nos termos do acórdão recorrido, existindo, portanto, motivo apto a ensejar a alteração para a mudança de sexo no registro civil, e a fim de que os assentos sejam capazes de cumprir sua verdadeira função, qual seja, a de dar publicidade aos fatos relevantes da vida social do indivíduo, forçosa se mostra a admissibilidade da pretensão do recorrente, devendo ser alterado seu assento de nascimento a fim de que nele conste o sexo feminino, pelo qual é socialmente reconhecido. - Vetar a alteração do prenome do transexual redesignado corresponderia a mantêlo em uma insustentável posição de angústia, incerteza e conflitos, que inegavelmente atinge a dignidade da pessoa humana assegurada pela Constituição Federal. No caso, a possibilidade de uma vida digna para o recorrente depende da alteração solicitada. $\mathrm{E}$, tendo em vista que o autor vem utilizando o prenome feminino constante da inicial, para se identificar, razoável a sua adoção no assento de nascimento, seguido do sobrenome familiar, conforme dispõe o art. 58 da Lei n. ${ }^{\circ} 6.015 / 73$. - Deve, pois, ser facilitada a alteração do estado sexual, de quem já enfrentou tantas dificuldades ao longo da vida, vencendo-se a barreira do preconceito e da intolerância. O Direito não pode fechar os olhos para a realidade social estabelecida, notadamente no que concerne à identidade sexual, cuja realização afeta o mais íntimo aspecto da vida privada da pessoa. E a alteração do designativo de sexo, no registro civil, bem como do prenome do operado, é tão importante quanto a adequação cirúrgica, porquanto é desta um desdobramento, uma decorrência lógica que o Direito deve assegurar. - Assegurar ao transexual o exercício pleno de sua verdadeira identidade sexual consolida, sobretudo, o princípio constitucional da dignidade da pessoa humana, cuja tutela consiste em promover o desenvolvimento do ser humano sob todos os aspectos, garantindo que ele não seja desrespeitado tampouco violentado em sua integridade psicofísica. Poderá, dessa forma, o redesignado exercer, em amplitude, seus direitos civis, sem restrições de cunho discriminatório ou de intolerância, alçando sua autonomia privada em patamar de igualdade para com os demais integrantes da vida civil. A liberdade se refletirá na seara doméstica, profissional e social do recorrente, que terá, após longos anos de sofrimentos, constrangimentos, frustrações e dissabores, enfim, uma vida plena e digna. - De posicionamentos herméticos, no sentido de não se tolerar "imperfeições" como a esterilidade ou uma genitália que não se conforma exatamente com os referenciais científicos, e, consequentemente, negar a pretensão do transexual de ter alterado o designativo de sexo e nome, subjaz o perigo de estímulo a uma nova prática de eugenia social, objeto de combate da Bioética, que deve ser igualmente combatida pelo Direito, não se olvidando os horrores provocados pelo holocausto no século passado. Recurso especial provido". (BRASIL. STJ, $3^{a}$ T. REsp 1008398. Rel. Ministra Nancy Andrighi, julg. 15.10.2009. DJe, 18 nov. 2009). 
seu estado natural, e veda a discriminação com base em características genéticas ${ }^{48}$.

As novas tecnologias no âmbito genético suscitam receios em diversas searas. As terapias gênicas e os mecanismos de manipulação embrionária pré-implantatória recordam os fantasmas das práticas nazistas de eugenia. A possibilidade técnica de clonagem humana banida em nosso ordenamento pela Lei de Biossegurança (Lei n 11.105, de 24 de março de 2005) - levanta o receio de um sujeito humano cujas características e limitações biológicas não sejam determinadas pelo acaso, mas pelo desejo de outro ser humano ${ }^{49}$.

No plano das relações privadas, as técnicas de modificação genética também produzem impacto no plano da propriedade intelectual ante a patenteabilidade de sequências de genes. O exemplo mais notório de algo próximo disso é caso de John Moore. Durante tratamento de leucemia no hospital da Universidade da Califórnia (UCLA), nos Estados Unidos, Moore teve suas células colhidas (linfócitos T) e foram feitas pesquisas e experiências que conduziram a uma linhagem celular, a qual foi patenteada pelos médicos e pelo hospital. Moore ajuizou uma ação em face da UCLA, mas foi vencido por 4 a 3 na Suprema Corte da Califórnia, que entendeu que, embora tenha havido violação na relação médico-paciente, as células em questão não eram únicas nem havia direito de propriedade sobre o próprio corpo.

Se a decisão em questão já é dramática, a hipótese de a patente recair sobre uma sequencia genética é assustadora ${ }^{50}$. Afirma-se, nessa seara, que a identidade genética é um bem jurídico sob tutela constitucional (BARACHO, 2005), guarnecido por um direito à identidade genética, não apenas no tocante à espécie humana como um todo, mas especificamente de cada indivíduo (ASCENÇÃO, 2004).

\footnotetext{
48 Disponível em: <http://migre.me/fOF3L>. Acesso em: 20 ago. 2013.

49 Sobre o tema, v. Habermas (2010).

50 Rodotà $(2004$, p.101) refere-se a uma sociedade americana que, para evitar o risco de furto de material genético, propôs-se a emitir um tipo de certificado de propriedade do genoma.
} 
Atribui-se à informação genética características que as tornam peculiares, como: a sua singularidade constitutiva, por consistir na identidade biológica de cada indivíduo; a sua estruturalidade, pois acompanha a existência daquele sujeito até a morte, de forma involuntária, indestrutível e permanente; a sua geracionalidade, por ser transmitida aos seus descendentes; e seu caráter probabilístico, pois indica as chances de desenvolvimento de doenças e características ao longo de sua vida. No entanto, como alerta Schiocchet (2012), essas peculiaridades não podem ser superestimadas a ponto de se cair em um reducionismo genético. O que elas revelam é que as informações genéticas são dados sensíveis, pois permitem identificar o sujeito, oferecer informações desconhecidas, revelar enfermidades futuras e incertas, dar informações sobre sua descendência e sobre outros parentes. Enfim, têm grande potencial para causar danos na esfera do livre desenvolvimento da personalidade.

Daí o grande receio acerca da coleta e utilização discriminatória de tais informações (ECHTRHOFF, 2010). Os exemplos principais encontram-se nas relações trabalhistas e nos contratos de seguro, mas se fala inclusive da existência de testes genéticos antenupciais ${ }^{51}$ (SEÑA, 1995). O acesso às informações genéticas permite aos empregadores tanto a seleção negativa de empregados mais propensos ao alcoolismo, à obesidade e à desatenção, como a seleção positiva daqueles com tendências maiores à disposição, capacidade de concentração e subserviência.

No âmbito dos seguros, o acesso a informações genéticas indicando tendências a problemas de coração, certos tipos de câncer, males neurológicos, como o Parkinson e o Alzheimer, e cada vez mais doenças que se tornam passíveis de identificação probabilística, tornam próxima a possibilidade do seguro sem risco.

Especificamente sobre os diagnósticos genéticos pré-matrimoniais, v. Malanda (2005, pp. 339374). 
Schreiber (2011) exemplifica no Brasil com o caso da jogadora de vôlei juvenil, Alessandra Januário, a "Neneca", que foi cortada da seleção após um teste genético detectar a presença de traço falciforme. Depois de grande controvérsia e após uma análise diferenciando traço falciforme e anemia falciforme, a Confederação Brasileira de Vôlei voltou atrás e reintegrou a atleta ${ }^{52}$.

Na Islândia, o interesse científico na identificação de doenças genéticas autorizou a construção de um banco de dados genéticos dos habitantes, administrado por uma sociedade americana com vínculos com a indústria farmacêutica (deCODE genetics). A repercussão da atividade aumentou quando a sociedade foi à falência em 2009 e veio à tona a discussão sobre a possibilidade de os dados já colhidos irem para a titularidade dos credores (SCHREIBER, 2011). Comprada pela Saga Investments $L L C$, a sociedade continua na atividade de pesquisa com os bancos de dados, a despeito da notícia de uma decisão contrária da Suprema Corte local. Ragnhildur Guðmundsdóttir, representada por sua mãe, Birna Pórðardóttir, ajuizou uma ação para que as informações genéticas de seu falecido pai não fossem transferidas para o banco de dados, o que foi garantido em grau de recurso, com base no direito à privacidade e na ausência de consentimento informado (GERTZ, 2004).

\section{A privacidade como poder negativo: o direito de não saber e o bloqueio do dever de informar}

Outra convergência possível entre privacidade como autodeterminação e corpo como informação se encontra no exercício do chamado "direito de não saber". Entendida a privacidade não apenas como a possibilidade de impedir que informações de seu conhecimento sejam acessadas por terceiros, mas também o direito de desconhecer certas informações a seu respeito que sejam de conhecimento de terceiros.

52 Informação disponível em <http://migre.me/fOFDE>. Acesso em: 20 ago. 2013. 
Essa configuração da privacidade como mecanismo de bloqueio do dever de informar se apresenta com frequência quando o próprio corpo é objeto da informação. O progresso tecnológico permitiu à ciência médica a obtenção de diversas informações sobre males que atingem ou atingirão o corpo sem, contudo, ter ainda permitido qualquer tratamento para tais males. Dessa forma, a reflexão sobre essa situação dramática conduz a uma relativização sobre o valor do conhecimento, à necessidade de se evitar algum tipo de "destino biológico" e à garantia do espaço do acaso como premissa ao exercício da liberdade existencial (RODOTÀ, 2008).

O exemplo da doença de Huntington, mal de origem cromossomial que se manifesta entre os 30 e os 50 anos e se desenvolve lentamente, provocando uma degeneração progressiva do cérebro e movimentos involuntários, sem qualquer tipo de tratamento, culminando com a morte do paciente em 10 a 15 anos, coloca claramente a adequação da privacidade também como poder negativo, "ou seja, como direito de excluir da própria esfera privada uma determinada categoria de informações" (RODOTÀ, 2008, pp. 108-109).

A fundamentação desse direito prima facie, em que pese alguma controvérsia, costuma ser atribuída de forma ampla à autonomia do paciente e sua liberdade individual, sem prejuízo de previsão específica em alguns ordenamentos e nas convenções internacionais relativas à bioética, como na Convenção Europeia de Direitos Humanos e Biomedicina e na Declaração da Unesco sobre o Genoma Humano ${ }^{53}$ (ANDORNO, 2003, on-line). A dificuldade, contudo, reside no contexto de sua aplicação in concreto.

A construção dessa modalidade de privacidade leva ao reconhecimento da sua violação como ato ilícito, isto é, o fornecimento da informação indesejada, no caso dos chamados "descobrimentos inesperados", deve ser prevenido e reprimido, ensejando o dever

53 Entre nós, v. Pereira (2011, p. 79). 
de indenizar o dano à pessoa decorrente da lesão à privacidade. No entanto, a ilicitude da prática pode ser afastada em virtude da tutela de outros interesses considerados juridicamente relevantes, muitas vezes presentes no caso concreto.

Exemplo controverso no cenário nacional se deu no processo de investigação, amplamente divulgado pela mídia, de Vilma Martins Costa. Acusada de ter sequestrado o menino Pedrinho da maternidade, criando-o como se fosse seu filho, foi realizado o exame de DNA comprovando a ausência de vínculo biológico, corroborando a tese do sequestro. As autoridades policiais, no entanto, suspeitavam que o sequestro de Pedrinho não fora um fato isolado e intimaram Roberta, sua outra filha, a fornecer material biológico para realização de exame de DNA. Embora ela tenha se recusado, a sua saliva foi recolhida das guimbas de cigarros fumados na delegacia durante o depoimento e foi realizado o exame que atestou a ausência de vínculo biológico entre ela e sua mãe de criação, sob o argumento da segurança pública, no tocante à investigação criminal ${ }^{54}$ (ANDERSON, 2011).

O direito de não saber também já foi objeto da jurisprudência do STJ. No caso, um paciente requisitou um exame anti-HCV, mas o laboratório se enganou e fez o exame anti-HIV, tendo encaminhado ao paciente a informação não solicitada de que ele era soropositivo. O caso é rico em dificuldades, na medida em que se colocam diversas circunstâncias específicas que podem ser relevantes na ponderação dos princípios em jogo.

Os ministros Massami Uyeda, Sidnei Benetti, Paulo de Tarso Sanseverino e Vasco Della Giustina, que formaram a maioria, entenderam que eram circunstâncias relevantes: (i) tratar-se de doença infectocontagiosa; (ii) existir campanha pelo exame; (iii) ser problema de saúde pública; (iv) não ter ocorrido comunicação a terceiros; (v) existir tratamento para a doença; (vi) e a informação ser correta.

54 Sobre o caso, v. Maia (2013). 
Votou vencida a ministra Nancy Andrighi, para quem nenhum desses elementos era suficiente para afastar a caracterização de violação da privacidade no caso concreto ${ }^{55}$.

\section{Conclusão}

"Por detrás da continuidade aparente na superfície das palavras está escondida uma descontinuidade radical na profundidade do sentido" (Hespanha, 1998, p. 18). O alerta de António Manuel é especialmente importante para aqueles que atuam no âmbito do Direito. A persistência dos mesmos termos induz ao erro de continuar a se referir aos seus significados originais, desconsiderando as transformações sociais ocorridas. Esse erro é especialmente grave ao tratar da privacidade, assim como do corpo.

Persistir a restringir a aplicação da privacidade à tutela do segredo, à proteção contra invasões e à inviolabilidade do isolamento importa

"RECURSO ESPECIAL - AÇÃO DE INDENIZAÇÃO POR DANOS MORAIS E MATERIAIS DECORRENTES DAREALIZAÇÃO DE EXAME DE HIV NÃO SOLICITADO, POR MEIO DO QUAL O PACIENTE OBTEVE A INFORMAÇÃO DE SER SOROPOSITIVO - VIOLAÇÃO AO DIREITO À INTIMIDADE - NÃO OCORRÊNCIA - INFORMAÇÃO CORRETA E SIGILOSA SOBRE SEU ESTADO DE SAÚDE - FATO QUE PROPORCIONAAO PACIENTE A PROTEÇÃO A UM DIREITO MAIOR, SOB O ENFOQUE INDIVIDUAL E PÚBLICO - RECURSO ESPECIAL IMPROVIDO. I - O direito à intimidade, não é absoluto, aliás, como todo e qualquer direito individual. Na verdade, é de se admitir, excepcionalmente, a tangibilidade ao direito à intimidade, em hipóteses em que esta se revele necessária à preservação de um direito maior, seja sob o prisma individual, seja sob o enfoque do interesse público. Tal exame, é certo, não prescinde, em hipótese alguma, da adoção do princípio da dignidade da pessoa humana, como princípio basilar e norteador do Estado Democrático de Direito, e da razoabilidade, como critério axiológico; II - Sob o prisma individual, o direito de o indivíduo não saber que é portador do vírus HIV (caso se entenda que este seja um direito seu, decorrente da sua intimidade), sucumbe, é suplantado por um direito maior, qual seja, o direito à vida, o direito à vida com mais saúde, o direito à vida mais longeva $\mathrm{e}$ saudável; III - Mesmo que o indivíduo não tenha interesse ou não queira ter conhecimento sobre a enfermidade que lhe acomete (seja qual for a razão), a informação correta e sigilosa sobre seu estado de saúde dada pelo Hospital ou Laboratório, ainda que de forma involuntária, tal como ocorrera na hipótese dos autos, não tem o condão de afrontar sua intimidade, na medida em que Ihe proporciona a proteção a um direito maior; IV - Não se afigura permitido, tão-pouco razoável que o indivíduo, com o desiderato inequívoco de resguardar sua saúde, após recorrer ao seu médico, que lhe determinou a realização de uma série de exames, vir à juízo aduzir justamente que tinha o direito de não saber que é portador de determinada doença, ainda que o conhecimento desta tenha se dado de forma involuntária. Tal proceder aproxima-se, em muito, 
não apenas equívoco científico, mas produz uma série de repercussões práticas desfavoráveis. Da mesma forma, deixar de reconhecer todas as implicações jurídicas da ressignificação social do corpo, com seu desmembramento e sua virtualização, implica desguarnecer a pessoa humana, especialmente diante das novas tecnologias.

Esse equívoco, em primeiro lugar, facilita a concepção da privacidade e do corpo como bens disponíveis, renunciáveis. A manifestação de vontade do titular, expressa ou tácita, resultante de uma pequena cláusula de um contrato, de um gesto em público ou de uma carreira de sucesso profissional nas artes, seria suficiente para pôr abaixo a proteção conferida aos demais. A partir daí, conduziria também à possibilidade de transação, de comércio desses bens. Os imperativos do mercado, ávido por informações que permitem dirigir venda de produtos, criar perfis de consumidor e satisfazer "desejos" induzidos pela mídia, prevaleceriam sobre a proteção da dignidade da pessoa humana. Enfim, privacidade e corpo seriam bens sacrificáveis em nome de exigências coletivas superiores, como a segurança. Alimentados pelo medo, real ou fabricado, os sujeitos abririam mão de seus espaços, de sua individualidade, de sua autonomia, enfim, de sua privacidade e de seu corpo, pois o cidadão correto nada teria a esconder.

\footnotetext{
da defesa em juízo da própria torpeza, não merecendo, por isso, guarida do Poder Judiciário; V - No caso dos autos, o exame efetuado pelo Hospital não contém equívoco, o que permite concluir que o abalo psíquico suportado pelo ora recorrente não decorre da conduta do Hospital, mas sim do fato de o recorrente ser portador do vírus HIV, no que o Hospital-recorrido, é certo, não possui qualquer responsabilidade; VI - Sob o enfoque do interesse público, assinala-se que a opção de o paciente se submeter ou não a um tratamento de combate ao vírus HIV, que, ressaltese, somente se tornou possível e, certamente, mais eficaz graças ao conhecimento da doença, dado por ato involuntário do Hospital, é de seu exclusivo arbítrio. Entretanto, o comportamento destinado a omitir-se sobre o conhecimento da doença, que, em última análise, gera condutas igualmente omissivas quanto à prevenção e disseminação do vírus HIV, vai de encontro aos anseios sociais; VII - Num momento em que o Poder Público, por meio de exaustivas campanhas de saúde, incentiva a feitura do exame anti HIV como uma das principais formas de prevenção e controle da disseminação do vírus HIV, tem-se que o comando emanado desta augusta Corte, de repercussão e abrangência nacional, no sentido de que o cidadão teria o direito subjetivo de não saber que é soropositivo, configuraria indevida sobreposição de um direito individual (que, em si não se sustenta, tal como demonstrado) sobre o interesse público, o que, data maxima venia, não se afigura escorreito; VII - Recurso Especial improvido. (BRASIL. STJ, 3 ${ }^{a}$ T. REsp 1195995/SP. Rel. Ministra Nancy Andrighi. Rel. p/ Acórdão Ministro Massami Uyeda, julgado em 22/03/2011, DJe, 06 abr. 2011). Para a análise do caso v. Mulholland (2011, pp. 179-188) e, no sentido oposto, Barbosa (2012, pp. 153-175).
} 
Não se trata de fatalismo ou determinismo, mas de reconhecer que a expansão do conceito jurídico de privacidade, convergindo com o conceito de corpo, destina-se exatamente a coibir esses movimentos incompatíveis com a proteção ao livre desenvolvimento da personalidade. Nessa linha, a privacidade contemporânea se expande como direito à autodeterminação informativa, para, reconhecendo nas pessoas "sujeitos de direito e não objeto de crédito" (FACHIN, 2005, p. 17), protegê-las também em sua manifestação mais concreta e pessoal: seu corpo. Assim, por exemplo, sua sexualidade, seu genoma e mesmo seu desconhecimento sobre o seu corpo são tutelados como informações cujo controle deve estar, necessariamente, nas mãos de seu titular.

Persistir na ideia de que a privacidade limita-se a impedir o Estado de invadir nossos sótãos em busca do retrato de Dorian Gray é menosprezar a amplitude desse direito e deixar desprotegido o controle das informações que já não se encontram mais sob a alçada do seu titular.

\section{Referências}

ANDORNO, Roberto. The right not to know: an autonomy based approach. Journal of Medical Ethics, v. 30, n. 5, 2003. Disponível em: <http://migre.me/fOFGH>. Acesso em: 12 ago. 2013.

ASCENÇÃO, José de Oliveira. Intervenções no genoma humano: validade ético-jurídica. In: LEITE, E. O. (Coord.). Grandes temas da atualidade: bioética e biodireito. Rio de Janeiro: Forense, 2004. p. 227249.

BARACHO, José Alfredo de Oliveira. Teoria geral da bioética e do biodireito. Biomédica. In: TEIXEIRA, S. F. (Org.). Direito e medicina: aspectos jurídicos da medicina. Belo Horizonte: Del Rey, 2005. p. 96110.

BARBOSA, Fernanda Nunes. O direito de não saber e os limites do dano indenizável. Revista Trimestral de Direito Civil, Rio de Janeiro, n. 51, p. 153-175, jul./set. 2012. 
BARBOZA, Heloísa Helena. Princípios da bioética e do biodireito. Revista Bioética, Brasília, DF, v. 8, n. 2, p. 210-219, 2000. Disponível em: <http://migre.me/fOEWa>. Acesso em: 20 ago. 2013.

BARBOZA, Heloísa Helena. Responsabilidade civil e bioética. In: MARTINS, Guilherme Magalhães (Coord.). Temas de responsabilidade civil. Rio de Janeiro: Lumen Juris, 2012. p. 481-497.

BARBOZA, Heloísa Helena; BARRETTO, Vicente. Biodireito. In: ARNAUD, André-Jean (Ed.). Dicionário enciclopédico de teoria e de sociologia do direito. Rio de Janeiro: Renovar, 1999. p.69-73.

BARBOZA, Heloisa Helena Gomes. Procedimentos para redesignação sexual: um processo bioeticamente inadequado. 2010. $174 \mathrm{f}$. Tese (Doutorado em Ciências na área de Saúde Pública.)-Escola Nacional de Saúde Pública Sérgio Arouca, Rio de Janeiro, 2010.

BGHZ 124, 52 VI. Civil Senate (VI ZR 62/93). Translated by Irene Snook. Institute of European and Comparative Law - University of Oxford. Disponível em: <http://migre.me/fOEYm>. Acesso em: 20 ago. 2013.

BIRMAN, Joel. A biopolítica na genealogia da psicanálise: da salvação à cura. Hist. Ciênc. Saúde, Rio de Janeiro, v.14, n.2, p. 529-548, abr./ jun. 2007.

BRANDEIS, Louis D.; WARREN, Samuel D. The right to privacy. Harvard Law Review, Cambridge, v. IV, n. 5, 15 dec. 1890. Disponível em: <http://migre.me/ciKpZ>. Acesso em: 20 ago. 2013.

BRASIL. Superior Tribunal de Justiça. $3^{a}$ Turma. Recurso Especial 1008398. Relatora: Ministra Nancy Andrighi. Julgamento 15 out. 2009. Dje, 18 nov. 2009. Disponível em: <http://goo.gl/gctObl>. Acesso em: 19 ago. 2013

BRASIL. Superior Tribunal Justiça. $3^{\text {a }}$ Turma. Recurso Especial 1195995/ SP. Relatora: Ministra Nancy Andrighi, Relator p/ Acórdão Ministro Massami Uyeda. Julgado em 22 mar. 2011. Dje, 6 abr. 2011. Disponível em: <http://goo.gl/EXYQh3>. Acesso em: 19 ago. 2013

BRAZIL: investigation opened over suspicions of illegal intelligence activities by mining company against social movements and human rights 
defenders. FIDH. Disponível em: <http://migre.me/fOEQz>. Acesso em: 20 ago. 2013.

CANGUILHEM, Georges. O normal e o patológico. Rio de Janeiro: Forense Universitária, 2000.

CARTA DOS DIREITOS FUNDAMENTAIS DA UNIÃO EUROPEIA. Disponível em: <http://migre.me/cjfZT>. Acesso em: 20 ago. 2013.

COSTA NETO, Paulo José da. O direito de estar só: a tutela penal da intimidade. São Paulo: Revista dos Tribunais, 1970.

DALSENTER, Thamis Ávila. Transexualidade: a (in) visibilidade imposta pelo judiciário. Revista Trimestral de Direito Civil, Rio de Janeiro, v. 31, p.193-206, jul./set. 2007.

DONEDA, Danilo. Da privacidade à proteção de dados pessoais. Rio de Janeiro: Renovar, 2006.

DONEDA, Danilo. A "placa eletrônica" e a privacidade na sociedade da vigilância. Mídia sem máscara. Disponível em: <http://migre.me/ fOENU>. Acesso em: 20 ago. 2013.

DUBY, George. Prefácio. In: VEYNE, Paul (Org.). História da vida privada. São Paulo: Companhia de Bolso, 2009. v. I.

ECHTERHOFF, Gisele. Direito à privacidade dos dados genéticos. Belo Horizonte: Juruá, 2010.

ESCOLA pública do DF testa chip para monitorar alunos. Estadão. Disponível em: <http://migre.me/fOF09>. Acesso em: 20 ago. 2013.

FACHIN, Luiz Edson. Luzes e sombras no diálogo entre direito e medicina. In: TEIXEIRA, S. F. (Org.). Direito e medicina: aspectos jurídicos da medicina. Belo Horizonte: Del Rey, 2005. p. 73-85.

FOUCAULT, Michel. Os anormais. São Paulo: Martins Fontes, 2001. Curso no Collège de France (1974-1975).

FOUCAULT, Michel. O nascimento da clínica. Rio de Janeiro: Forense Universitária, 1977. 
GARATTONI, Bruno. Nova ferramenta do Google controla os seus dados após a sua morte. Superinteressante, 12 abr. 2013. Disponível em: <http://migre.me/fOEq2>. Acesso em: 20 ago. 2013.

GERTZ, Enate. An analysis of the Icelandic Supreme Court judgement on the Health Sector Database Act. SCRIPTed, v. 1, n. 2, 241-258, 2004. Disponível em: <http://migre.me/fOFEX>. Acesso em: 20 jul. 2013.

GLANCY, Dorothy. Privacy and the other Miss M. Summer, 1990. Symposium on the right to privacy: after one hundred years, 10, n. III, U. L. Rev. 401. Disponível em: <http://migre.me/ciK8C>. Acesso em: 9 dez. 2012.

GREENFIELD, Rebecca. At Davos, Marissa Mayer gets real on privacy. Atlantic Wire. Disponível em: <http://migre.me/fOEk3>. Acesso em: 20 ago. 2013.

GUEDES, Cristiano; DINIZ, Débora. Um caso de discriminação genética: o traço falciforme no Brasil. Physis: Revista de Saúde Coletiva, Rio de Janeiro, v. 17, p. 501-520, 2007.

HABERMAS, Jürgen. O futuro da natureza humana. São Paulo: Martins-Fontes, 2010.

HARRIS, Shane. TIA Lives On. National Journal, 23 feb. 2006. Disponível em: <http://migre.me/fOEKw>. Acesso em: 20 ago. 2013.

HESPANHA, António Manuel. Panorama histórico da cultura jurídica europeia. 2. ed. Lisboa: Europa-América, 1998.

HORNUNG, Gerrit; SCHNABEL, Christoph. Data protection in Germany I: the population census decision and the right to informational selfdetermination. Computer Law \& Security Report, v. 25, n. 1, p. 8488, 2009. Disponível em: <http://migre.me/fOETX>. Acesso em: 20 ago. 2013.

INTERBRAND. Best global brands, 2012. Disponível em: <http://migre. me/cjc2u>. Acesso em: 9 dez. 2012.

JOGADORES poderão usar chips para monitorar estado de saúde durante as partidas. Disponível em: <http://migre.me/fOF18>. Acesso em: 20 ago. 2013. 
KONDER, Carlos Nelson O consentimento no biodireito: os casos dos transexuais e dos wannabes. Revista Trimestral de Direito Civil, Rio de Janeiro, v. 15, p. 61-73, jul./set. 2003.

LEMENNICIER, Bertrand. L'idée que le corps humain dans ses parties n'est pas un objet mais un sujet est un postulat philosophique dont la valeur est hautement contestable: le corps humain: proprieté de l'État ou proprieté de soi?. Droits, n. 13, PUF, p. 114, 1991.

LEWICKI, Bruno. A privacidade no ambiente de trabalho. Rio de Janeiro: Renovar, 2003.

LEWICKI, Bruno. Realidade refletida: privacidade e imagem na sociedade vigiada. Revista Trimestral de Direito Civil, Rio de Janeiro, v. 27, p. 211-219, jul./set. 2006.

LÔBO, Paulo Luiz Netto. Autolimitação do direito à privacidade. Revista Trimestral de Direito Civil, Rio de Janeiro, v. 34, p. 102 -124, abr./jun. 2008.

MACHADO, Diego Carvalho. Autonomia privada, consentimento e corpo humano: para a construção da própria esfera privada na era tecnológica. Revista Trimestral de Direito Civil, Rio de Janeiro, v. 37, p. 39-45, jan./mar. 2009.

MAIA, Cecília. A farsa chega ao fim. Istoé Gente. Disponível em: <http:// migre.me/fOFJ6>. Acesso em: 20 ago. 2013.

MALANDA, Sérgio Romeo. A incidência da genética no direito (humano) ao matrimônio. In: CASABONA, C. M. R.; QUEIROZ, J. F. (Coord.). Biotecnologia e suas implicações jurídicas. Belo Horizonte: Del Rey, 2005. p. 339-374.

MARTINS, Luiz Alberto Moreira; PEIXOTO JUNIOR, Carlos Augusto. Genealogia do biopoder. Psicol. Soc., Florianóplis, v. 21, n. 2, p. 157165, 2009.

MARTINS, Raphael Mosaico. o 'Prism' brasileiro. Galieu. Disponível em: <http://migre/fOEPs>. Acesso em: 20 ago. 2013.

MOORE v. Regents of the University of California (51 Cal. 3d 120; 271 
Cal. Rptr. 146; 793 P.2d 479). Disponível em: <http://migre.me/fOFb7>. Acesso em: 20 ago. 2013.

MORAES, Alexandre de. A implantação do chip para identificação eletrônica dos veículos é uma boa medida? Sim. Segurança, qualidade de vida e privacidade. Folha de São Paulo, 13 out. 2007. Disponível em: <http://migre.me/fOENo> . Acesso em: 20 ago. 2013.

MORAES, Maria Celina Bodin de. Ampliando os direitos da personalidade: na medida da pessoa humana. Rio de Janeiro: Renovar, 2010c.

MORAES, Maria Celina Bodin de. Constituição e direito civil: tendências: na medida da pessoa humana. Rio de Janeiro: Renovar, 2010a.

MORAES, Maria Celina Bodin de. O princípio da solidariedade: na medida da pessoa humana. Rio de Janeiro: Renovar, 2010b.

MULHOLLAND, Caitlin Sampaio. O direito de não saber como decorrência do direito à intimidade. Revista Trimestral de Direito Civil, Rio de Janeiro, n. 46, p. 179-188, abr./jun. 2011.

NUNES, Márcio Tadeu Guimarães. Lei de acesso à informação: reconstrução da verdade histórica, ambientes regulatórios e o direito à intimidade. São Paulo: Quartier Latin, 2013.

ORTEGA, Francisco. O corpo incerto. Rio de Janeiro: Gramond, 2008.

PEREIRA, Caio Mário da Silva. Instituições de direito civil. 23. ed. Rio de Janeiro: Forense, 2010. v. 1.

PEREIRA, Paula Moura Francesconi de Lemos. Relação médicopaciente: o respeito à autonomia do paciente e a responsabilidade civil do médico pelo dever de informar. Rio de Janeiro: Lumen Juris, 2011.

PERES, Ana Paula Ariston Barion. Transexualismo: o direito a uma nova identidade sexual. Rio de Janeiro: Renovar, 2001.

PERLINGIERI, Pietro. O direito civil na legalidade constitucional. Rio de Janeiro: Renovar, 2012. 
PERLINGIERI, Pietro. Perfis do direito civil. Tradução Maria Cristina De Cicco. 2. ed. Rio de Janeiro: Renovar, 2002.

PLASTINO, Carlos Alberto. Os horizontes de Prometeu: considerações para uma crítica da modernidade. Cadernos de Teoria Política Moderna, Rio de Janeiro, ano II, n.1, p. 12-13, 1996.

POUSSON-PETIT, Jacqueline. Une illustration: le cas du transexualisme. In: NEIRINCK, Claire (Dir.). De la bioéthique au bio-droit. Paris: L.G.D.J., 1994. p. 143-147.

PUBLICITÁRIO aluga coxa de mulheres para fazer propaganda em Tóquio. Globonews. Disponível em: <http://migre.me/fOEsY>. Acesso em: 20 ago. 2013.

REICH, Warren (Ed.). Encyclopedia of bioethics. New York: MacMillan, 1979.

RIO DE JANEIRO (Estado). Tribunal de Justiça. 4ª Câmara Cível. Apelação Civel. 4.425/93, e o caso notório de Luis Roberto Gambine Moreira. Relator Desembargador Luiz Carlos Guimarães. Apelo provido. (JRC), v. u., j. em 10 maio 1994. Revista Forense, 1994.

RIO DE JANEIRO (Estado). Tribunal de Justiça. $8^{a}$ Câmara Cível. Apelação Civel. 1993.001.06617. Relator Desembargador Geraldo Batista, v.u. Julgamento. 18 mar. 1997. Ementário: 07/1997 - n. 36 15/05/1997. Revista Direito do T.J.E.R.J., v. 33, p. 189, 1997.

RIO DE JANEIRO (Estado). Tribunal de Justiça. $8^{a}$ Câmara Cível. Apelação Civel. n. 1993.001.04425. Relator Desembargador Luiz Carlos Guimarães. Julgamento 10 maio 1994. Ementário: 29/1994 - n. 19 06/10/1994. Revista Forense, v. 328, p.196, 1994.

RIO GRANDE DO SUL. Tribunal de Justiça. 3a Câmara Cível. Apelação Civel. 597156728. Rel. Desembargador. Tael João Selistre. Julg. 18 dez. 1997. Disponível em:< http://goo.gl/U9NoGV>. Acesso em: 20 ago. 2013

RODOTÀ, Stefano. Autodeterminazione e laicità: perché laico. Bari: Laterza, 2010. 
RODOTÀ, Stefano. A vida na sociedade da vigilância. Rio de Janeiro: Renovar, 2008.

RODOTÀ, Stefano. La vita e le regole: tra diritto e non diritto. Milano: Feltrinelli, 2009.

RODRIGUES, José Carlos. Tabu do corpo. 4. ed. Rio de Janeiro: Dois Pontos, 1986.

SAMPAIO, Adércio Leite José. Direito à intimidade e à vida privada: uma visão jurídica da sexualidade, da família, da comunicação e informações pessoais, da vida e da morte. Belo Horizonte: Del Rey, 1998.

SARMENTO, Daniel. A trajetória da dicotomia público/privado. Revista Trimestral de Direito Civil, Rio de Janeiro, v. 22, p. 239-257, abr./jun. 2005.

SCHREIBER, Anderson. Direitos da personalidade. São Paulo: Atlas, 2011.

SCHIOCCHET, Taysa. Acesso às informações genéticas humanas e direitos da personalidade: impactos sobre o consentimento informado. In: TEPEDINO, G.; FACHIN, L. E. (Coord.). Diálogos sobre direito civil. Rio de Janeiro: Renovar, 2012. v III. p. 410-443.

SEÑA, Jorge F. Malem. Isonomía: Revista de Teoría y Filosofía del Derecho. Cidade do México, n. 2, p. 159-183, 1995.

SOLOVE, Daniel J. Conceptualizing privacy. California Law Review, California, v. 90, p. 1087-1155, 2002.

SOLOVE, Daniel J. Nothing to hide: the false tradeoff between privacy and security. New Haven: Yale University Press, 2011.

TAIPALE, K. A. Data mining and domestic security: connecting the dots to make sense of data. Columbia Science and Technology Law Review, v. 5, n. 2, Dec. 2003. Disponível em: <http://migre.me/fOEKc>. Acesso em: 20 ago. 2013.

TEIXEIRA, Ana Carolina Brochado. Saúde, corpo e autonomia privada. Rio de Janeiro: Renovar, 2010. 
TEIXEIRA, Ana Carolina Brochado; KONDER, Carlos Nelson. Situações jurídicas dúplices: controvérsias na nebulosa fronteira entre patrimonialidade e extrapatrimonialidade. In: TEPEDINO, G.; FACHIN, L. E. (Org.). Diálogos sobre direito civil. Rio de Janeiro: Renovar, 2012. v. III. p. 3-24.

TEIXEIRA, Daniele Chaves. Breves considerações sobre a privacidade da pessoa notória no espaço público. In: TEPEDINO, G.; FACHIN, L. E. (Org.). Diálogos sobre direito civil. Rio de Janeiro: Renovar, 2012. v. II. p.197-217.

TEPEDINO, Gustavo. Premissas metodológicas para a constitucionalização do direito civil. 4. ed. Rio de Janeiro: Renovar, 2008. (Temas de direito civil).

XAVIER, Elton Dias. A identidade genética do ser humano como um biodireito fundamental e sua fundamentação na dignidade do ser humano. In: LEITE, E. O. (Coord.). Grandes temas da atualidade: bioética e biodireito. Rio de Janeiro: Forense, 2004. p. 55-85.

Recebido em: 15/07/13

Aprovado em: 25/07/13 